\title{
PENILAIN KETIDAKPASTIAN DATA MODEL PERUBAHAN IKLIM DENGAN METODE CDFDM DI WILAYAH SUMATERA BARAT
}

\author{
Sugeng Nugroho ${ }^{1^{*}}$, Rudi Febriamansyah ${ }^{2}$, Robi Muharsyah ${ }^{3}$ \\ ${ }^{1}$ Stasiun Klimatologi Padang Pariaman, BMKG, Sumatera Barat. Jln Padang-Bukittinggi Km.51, Sicincin, \\ Padang Pariaman, Sumatera Barat, 25584, Indonesia. \\ ${ }^{2}$ Program Studi Ilmu-Ilmu Pertanian, Pascasarjana, Universitas Andalas. Kampus Unand Limau Manis, \\ Padang, Sumatera Barat, 25163, Indonesia \\ ${ }^{3}$ Sub-bidang Analisis dan Informasi Klimatologi BMKG, Jakarta. Jln.Angkasa I, No. 2, Kemayoran, Jakarta \\ Pusat, 10720, Indonesia. \\ *sugeng_ho@yahoo.com
}

\begin{abstract}
Abstrak
Dampak perubahan iklim yang terjadi pada suatu wilayah sangat tergantung sensitivitas faktor lokal dalam merespon perubahan iklim global yang terjadi, sehingga sangat penting untuk melakukan koreksi data perubahan iklim global dengan data observasi di lokasi. CDFDM merupakan salah satu metode koreksi bias yang dapat digunakan untuk melakukan koreksi tersebut. Tujuan utama dari penelitian ini adalah untuk mengetahui ketidakpastian (uncertainty) data curah hujan, suhu maksimum dan suhu minimum hasil downscaling dari lima model GCMs, yaitu MIROC-ESM, MIROC-ESM-CHEM, MPI-ESM-MR, MPI-ESM-LR dan MRI-CGCM3 di wilayah Sumatera Barat. Data yang digunakan terdiri dari dua kelompok utama: data model GCMs dan observasi. Data observasi bersumber dari stasiun pengamatan BMKG Sumatera Barat dalam periode waktu 1981-2015. Untuk mengetahui ketidakpastian antara dua kelompok data digunakan metode PBIAS, MAE dan RMSE. Hasil penelitian menunjukkan bahwa CDFDM dapat mengurangi terjadinya bias antara data GCMs dan data Observasi ditunjukan dengan nilai bias yang lebih kecil. Namun besarnya kesalahan (magnitude error) tetap tidak dapat terkoreksi, ditunjukan oleh nilai RMSE dan MAE yang lebih besar setelah dilakukan koreksi. Dari kelima model telihat bahwa model MPIESM-LR dan MPI-ESM-MR memiliki performa terbaik dalam memproyeksikan data curah hujan dan suhu udara minimum. Sedangkan untuk suhu udara maksimum, selain kedua model tersebut model MIROC-ESM dan MIROC-ESM-CHEM, juga mempunyai tingkat performa yang hampir sama, baik di wilayah dataran rendah maupun dataran tinggi Sumatera Barat pada periode data tersebut
\end{abstract}

Kata kunci : uncertainty, GCMs, bias koreksi, CDFDM, Sumatera Barat.

(C) 2017 Sugeng Nugroho, Rudi Febriamansyah, Robi Muharsyah

\section{PENDAHULUAN}

Pertanian merupakan salah satu sector yang akan terkena dampak perubahan iklim paling besar, hal ini dikarenakan sifat ketergantungannya kepada faktor iklim, terutama hujan dan suhu udara yang sangat berpengaruh terhadap ketersediaan sumberdaya air untuk pertanian. (Palazzoli, dkk., 2015). Dampak tersebut terutama akan berpengaruh pada produktivitas hasil pertanian. Variabilitas produksi pertanian secara tidak langsung akan mempengaruhi kesejateraan petani. Untuk mensimulasikan dampak tersebut diperlukan data model perubahan iklim atau juga sering disebut sebagai data Global Climate Model (GCMs) yang telah secara luas digunakan untuk lebih memahami perubahan iklim. Dalam laporannya IPCC AR5 telah merilis 42 model GCMs terbaru dengan menggunakan beberapa variasi scenario (RCPs), rendah (RCP2.6), menengah pertama (RCP4.5), 
menengah kedua (RCP6.0) dan tinggi (RCP8.5) (IPCC, 2013).

Data GCMs tidak dapat secara langsung digunakan untuk menggambarkan dampak perubahan iklim dalam sekala lokal, dikarenakan data GCMs mengandung nilai ketidakpastian (uncertainty) sebagai konsekuensi dari kasarnya resolusi spasial dan ketidakmampuannya menangkap fitur-fitur fenomena dalam sekala yang lebih kecil, seperti topografi dan penggunaan lahan. Penggunaan data asli dari sebuah data GCMs akan berpotensi menghasilkan suatu kesimpulan yang menyesatkan. Untuk itu diperlukan tindakan downscaling untuk mendapatkan data GCMs dengan tingkat reolusi yang lebih tinggi.

Penilain ketidakpastian data GCMs menjadi penting untuk dilakukan, apalagi bila hasil simulasi akan digunakan sebagi salah satu pertimbangan dalam membuat strategi adaptasi di sektor pertanian. Ketidakpastian dari nilai yang sifatnya tunggal akan lebih besar (overconfidence), karena tidak ada pembanding. Untuk itu digunakan nilai ensambel dari beberapa nilai model sehingga, walaupun tetap ada nilai ketidakpastiannya namun terdapat nilai pembanding sebagai alternative pengambilan keputusan. Nilai ketidakpastian dari proyeksi iklim tidak hanya berasal dari model-model itu sendiri akan tetapi juga berasal dari bagaimana model tersebut dipilih sesuai dengan kebutuhannya. Nilai-nilai ketidakpastian akan selalu muncul selama model digunakan dalam menilai dampak potensial sektor pertanian terhadap perubahan iklim, terutama dalam melakukan proyeksi iklim pada masa yang akan datang. Ketidakpastian muncul sebagai bentuk konsekuensi dari kualitas data model iklim yang digunakan untuk mensimulasikan model pertanian (Cammarano, dkk., 2016). Untuk itu tujuan utama dari penelitian ini adalah untuk mengetahui ketidakpastian (uncertainty) data curah hujan, suhu maksimum dan suhu minimum hasil downscaling dari lima model GCMs, yaitu MIROC-ESM, MIROC-ESMCHEM, MPI-ESM-MR, MPI-ESM-LR dan MRI-CGCM3 di wilayah Sumatera Barat dengan menggunakan metode koreksi bias CDFDM.

\section{BAHAN DAN METODA}

\subsection{Lokasi Penelitian}

Penelitian akan dilakukan di wilayah Sumatera Barat, yang akan dibagi menjadi wilayah dataran rendah dan dataran tinggi. Wilayah dataran rendah akan diwakili dengan data pengamatan di Teluk Bayur (TLB), Tabing (TAB) dan Sicincin (SCN). Sementara Padang Panjang (PPJ) dan Bukit Kototabang (BKT) mewakili data iklim di wilayah dataran tinggi, seperti terlihat pada Gambar 2.

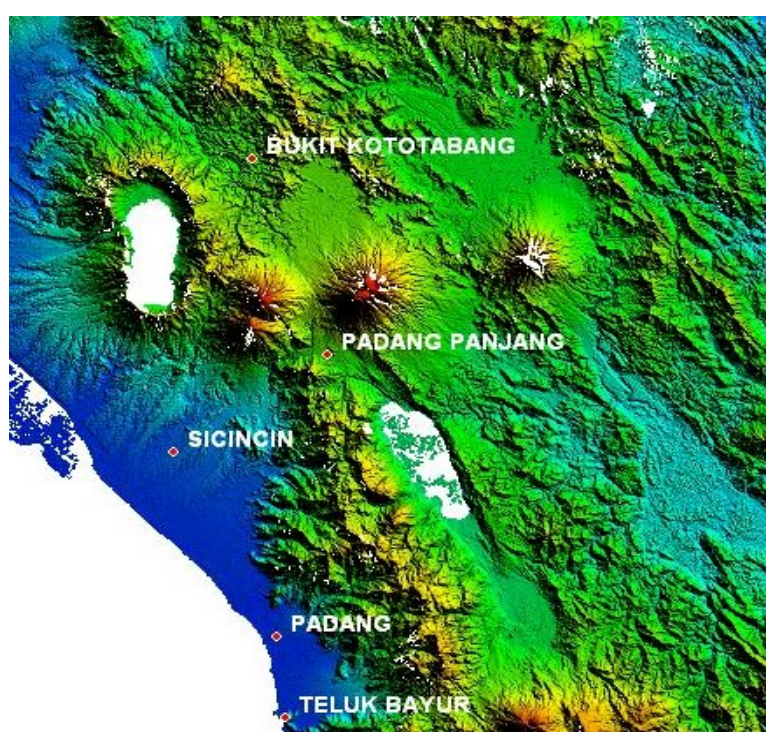

Gambar 1. Lokasi penelitian (citra srtm, 2011)

\subsection{Data}

Data yang akan digunakan dalam penelitian ini terbagi ke dalam dua kelompok besar, yaitu data iklim hasil observasi dan data model perubahan iklim, yang terdiri dari unsur iklim curah hujan (Pr), suhu udara maksimum (Tx) dan suhu udara minimum (Tn) dalam resolusi waktu harian. Data observasi tersebut bersumber dari hasil pengamatan BMKG Sumatera Barat, selama periode 20-30 tahun terakhir. Sebagian dari data tersebut dapat diakses melalui secara online di halaman website: dataonline.bmkg.go.id. Ketersediaan data dan diskripsi lingkungan lokasi penelitian data seperti terlihat pada Tabel 1 . 
Tabel 1. Diskripsi lokasi pengamatan dan ketersediaan data

\begin{tabular}{|l|c|c|c|l|l|c|c|}
\hline \multicolumn{1}{|c|}{ Lokasi } & Lon & Lat & $\begin{array}{c}\text { Elev } \\
(\mathrm{mdpl})\end{array}$ & $\begin{array}{c}\text { Lingkungan } \\
\text { dominan }\end{array}$ & \multicolumn{2}{|}{ Topografi } & \multicolumn{2}{c|}{ Periode Data } \\
\cline { 5 - 8 } & & & & & Awal & Akhir \\
\hline BKT & 100.320 & -0.200 & 865 & Remote area & Dataran tinggi & 1997 & 2015 \\
\hline PPJ & 100.416 & -0.471 & 783 & Urban & Dataran tinggi & 1991 & 2015 \\
\hline SCN & 100.267 & -0.567 & 137 & Sub-urban & Dataran rendah & 1985 & 2015 \\
\hline TAB & 100.362 & -0.874 & 3 & Urban & Dataran rendah & 1982 & 2015 \\
\hline TLB & 100.072 & -1.101 & 2 & Urban & Dataran rendah & 1994 & 2015 \\
\hline
\end{tabular}

Model data GCMs yang digunakan dalam penelitian ini model MRI-CGCM3, MIROCESM, MIROC-ESM-CHEM, MPI-ESM-LR, dan MPI-ESM-MR dengan menggunakan skenario perubahan iklim RCP4.5 dan RCP8.5. Representative Concentration Pathways (RCPs) merupakan scenario perubahan iklim dengan menggunakan tingkat perubahan iklim dengan dasar tingkat radiative forcing di atmosfer dengan mempertimbangkan kondisi iklim saat ini. Data-data tersebut merupakan sebagian dataset yang disediakan oleh NASA Earth Exchange Global Daily Downscale Projection (NEX-GDDP) pada proyek NASA Center for Climate Simulation (NCCS). NEXGDDP dihasilkan dengan menggunakan metode Bias-Correction Spatial Disaggregation (BCSD), metode statistik downscaling tipe regresi yang secara khusus dikembangkan untuk mengatasi keterbatasan proyeksi GCMs, yaitu cakupan resolusi spasial yang masih kasar dan masalah akurasi pada sekala global namun mempunyai bias yang cukup tinggi pada sekala lokal (Bao dan Wen, 2016). Data berformat grid netCDF dengan resolusi waktu harian dan resolusi spasial $0.25^{\circ}$ $\mathrm{x} \quad 0.25^{\circ}$, dengan periode tahun 1950-2005 (historical) dan 2006-2100 (projection) pada scenario RCP4.5 dan RCP8.5. Data model GCMs dapat diakses melalui ftp.nccs.nasa.gov. Diskripsi dari masing-masing model seperti terlihat pada Tabel 2 .

Tabel 2. Diskripsi Data Model Perubahan Iklim

\begin{tabular}{|c|c|c|c|c|}
\hline \multirow{2}{*}{ Nama Model } & \multicolumn{2}{|l|}{ Pengembang } & \multicolumn{2}{|c|}{ Periode Data } \\
\hline & Institusi & Negara & Historical & Proyeksi \\
\hline MRI-CGCM3 & $\begin{array}{l}\text { Meteorological Research } \\
\text { Institute }\end{array}$ & Jepang & $1950-2005$ & $2006-2100$ \\
\hline MIROC-ESM & $\begin{array}{l}\text { JAMSTEC-University of } \\
\text { Tokyo-NIES }\end{array}$ & Jepang & $1950-2005$ & $2006-2100$ \\
\hline MIROC-ESM-CHEM & $\begin{array}{l}\text { JAMSTEC-University of } \\
\text { Tokyo-NIES }\end{array}$ & Jepang & $1950-2005$ & $2006-2100$ \\
\hline MPI-ESM-LR & $\begin{array}{l}\text { Max Planck Intitute for } \\
\text { Meteorology }\end{array}$ & Jerman & $1950-2005$ & $2006-2100$ \\
\hline MPI-ESM-MR & $\begin{array}{l}\text { Max Planck Intitute for } \\
\text { Meteorology }\end{array}$ & Jerman & $1950-2005$ & $2006-2100$ \\
\hline
\end{tabular}

1.3. Pengolahan Data

1.3.1. Ekstraksi Data GCMs

Data-data perubahan iklim pada masingmasing lokasi (Tabel 1) ditentukan dengan melakukan ekstraksi terhadap data GCMs yang digunakan dalam penelitian ini (Tabel
2), seperti yang diilustrasikan pada Gambar 2. Selanjutnya dilakukan koreksi terhadap data hasil ektraksi tersebut. Koreksi perlu dilakukan karena data GCMs mempunyai tingat kekasaran yang relative tinggi, terutama dalam sekala ruang. 


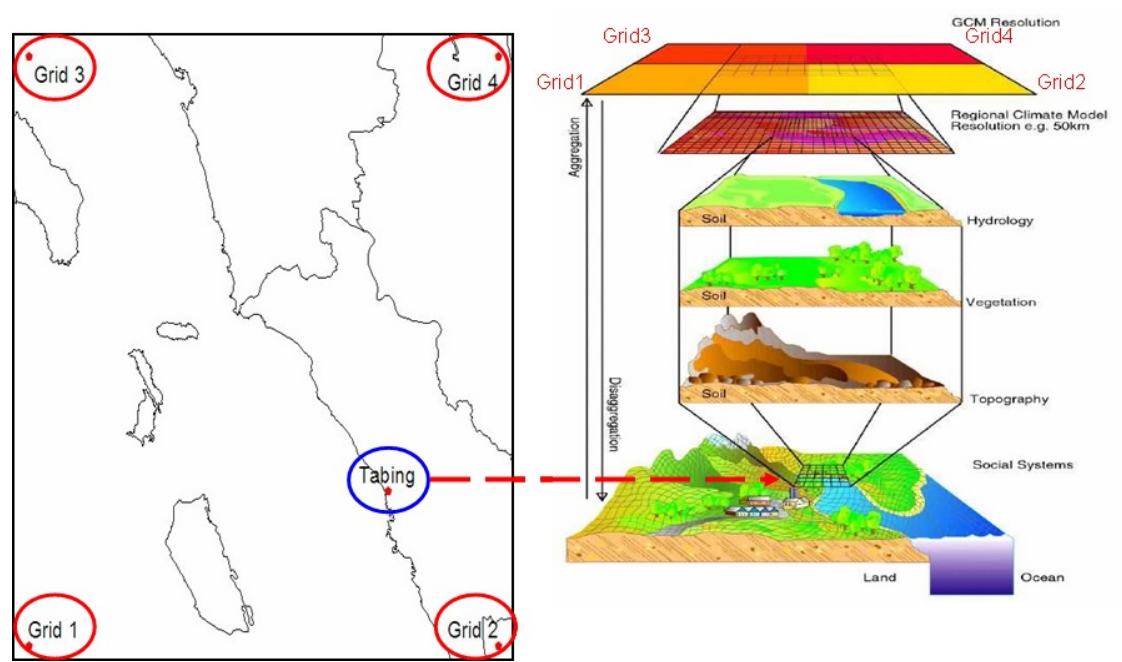

Gambar 2. Ilustrasi proses ekstrak data GCMs di lokasi Tabing terhadap titik-titik grid pada data model GCMs. (modifikasi dari Wilby, at al, 2007)

\subsubsection{Koreksi Bias dengan CDFDM}

Dalam penelitian ini koreksi terhadap data GCMs menggunkan metode koresi bias (bias correction/BC), yaitu Cumulative Distribution Function based Downscaling Method (CDFDM). (Iizumi, dkk., 2011). Worksheet program CDFDM dibuat untuk memudahkan penggunaan metode koreksi bias tersebut (Tonouchi dan Chiba, 2015). Secara ringkas langkah-langkah dari $\mathrm{BC}$ dengan menggunkan metode CDFDM sebagai berikut:

a) Dapatkan Cumulative Disrtibution Function (CDF) dari data observasi dan data GCMs pada periode tertentu (disebut sebagai periode training).

b) Hitung selisih curah hujan harian antara data GCMs terhadap data observasi pada tiap-tiap nilai fungsi CDF $F(0 \leq F \leq 1)$.

c) Dapatkan CDF dari data GCMs sepanjang periode data yang akan didownscaling dan tambahkan nilai selisih pada langkah b) untuk tiap-tiap nilai fungsi CDF yang bersesuaian.

d) Diperoleh data GCMs yang telah terkoreksi.

Proses CDFDM bergantung pada panjangnya data training yang dipakai. Data training adalah data observasi yang dipakai untuk mengoreksi data model. Pada kajian ini digunakan periode data bervariasi sesuai ketersediaan data yang ada pada masingmasing lokasi penelitian. Semakin panjang periode data training maka diasumsikan hasil koreksi akan semakin baik. Hal ini disebabkan semakin banyaknya berbagai kemungkinan kejadian curah hujan (termasuk curah hujan ekstrim) yang dipertimbangkan dalam proses koreksi CDFDM. Setelah diperoleh data GCMs yang terkoreksi (selanjutnya disebut data terkoreksi), data ini kemudian divalidasi dengan data observasi. Proses validasi dilakukan dengan melakukan uji validitas antara data observasi dan data terkoreksi dengan menghitung PBIAS, RMSE dan MAE dari masing-masing parameter iklim yang diproyeksikan.

\subsubsection{Metode Validasi Data \\ a) PBIAS}

Persen bias (PBIAS) dapat diartikan sebagai arah rata-rata simpangan dari nilai data yang diamati, namun bias tidak mencerminkan besarnya kesalahan (magnitude of the error) dari nilai data tersebut. Bias positif menunjukkan bahwa nilai data prakiraan/model lebih tinggi dibandingkan nilai observasinya, sementara bias negatif menunjukan nilai data prakiraan/model yang lebih rendah dari nilai 
observasi. Bias dapat dinyatakan sebagai penjumlahan nilai prakiraan/model dikurangi nilai observasinya dibagi dengan jumlah data, seperti yang tercantum pada persamaan 1 .

$$
\text { PBIAS }=\frac{\sum_{i=1}^{N}\left(M_{i}-O_{i}\right)}{N} x 100 \% \ldots \ldots \ldots \ldots(1)
$$

b) Mean Absolute Error (MAE)

Nilai serangkaian data prakiraan/model dengan jumlah $\mathrm{N}$ dimana $\mathrm{Mi}$ mewakili niai prakiraan/model ke-i dan Oi sebagai data observasi yang sesuai, maka kesalahan absolut rata-rata (mean absolute error/MAE) dinyatakan sebagai:

$$
M A E=\frac{\sum_{i=1}^{N}\left|M_{i}-O_{i}\right|}{N} \ldots \ldots \ldots \ldots \ldots \ldots . . .(2)
$$

MAE dapat merepresentasikan besarnya rata-rata kesalahan (magnitude of the error), tapi bukan arah penyimpangannya (direction of the deviation).

c) Root Mean Sequare Error (RMSE)

RMSE merupakan penilaian besarnya rata-rata kesalahan tertimbang menurut kuadrat kesalahan (Persamaan 3). Seperti halnya MAE, itu tidak menunjukkan arah penyimpangannya. RMSE lebih memberikan bobot/besaran pada kesalahan-kesalahan yang besar, sehingga sangat tepat digunakan untuk mencari kesalahan besar sangat. Sensitivitas terhadap kesalahan besar juga berarti bahwa hal itu mungkin tidak memberikan perkiraan kesalahan yang stabil jika sampel kecil digunakan, untuk itu RMSE akan tepat dihunkan bila sampel datanya berjumlah besar.

$$
R M S E=\sqrt{\frac{\sum_{i=1}^{N}\left(M_{i}-O_{i}\right)}{N}}
$$

Jika dibandingkan dengan MAE, RMSE dapat memberikan indikasi nilai varian kesalahan, yaitu jika nilai RMSE > MAE, maka hal ini menunjukkan varian kesalahan yang tinggi, sedangkan jika nilai RMSE =
MAE, maka semua kesalahan memiliki besaran yang sama dan nilai RMSE tidak akan pernah lebih kecil dari nilai MAE. (Stanski, dkk., 1989)

Prosentase besarnya nilai perubahan iklim, dilakukan dengan membandingkan antara data hasil proyeksi tahun 2020-2040 terhadap baseline-nya, dengan periode data yang bervariasi tergantung ketersediaan data pada masing-masing lokasi penelitian, menggunakan persamaan matematis sederhana berikut:

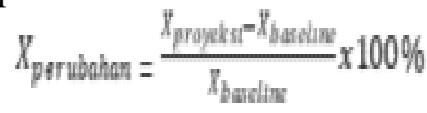

dimana $\mathrm{X}$ adalah unsur-unsur iklim (Pr, Tx dan $\mathrm{Tn})$

HASIL DAN PEMBAHASAN (Times New Roman 11, bold)

1.4. Hasil Ektraksi Data GCMs

Persentase perubahan jumlah curah hujan tahunan (PRCPTOT), merupakan rata-rata jumlah curah hujan tahunan pada tahun proyeksi (2020-2040) hasil downscaling model GCMs di lokasi penelitian dibandingkan dengan data baseline-nya. Hasilnya seperti terlihat pada Gambar 3, dimana semua model GCMs menunjukan terjadi peningkatan PRCPTOT dengan besaran persentase yang bervariasi antara $12-22 \%$ di wilayah dataran tinggi dan $15-23 \%$ di wilayah dataran rendah pada lokasi penelitian. Model MRI-CGCM3 menunjukan persentase perubahan terendah diikuti model MIROC-ESM-CHEM. Sedangkan prosentase perubahan tertinggi hasil dari model MPI-ESM-LR, diikuti MIROC-ESM dan MPI-ESM-MR. Secara umum dari keseluruhan model menunjukan bahwa wilayah dataran tinggi akan mengalami peningkatan PRCPTOT sekitar $17 \%$ sedangkan di wilayah dataran rendah sebesar $19 \%$.

Persentase perubahan suhu udara maksimum, merupakan rata-rata suhu udara maksimum tahunan pada tahun proyeksi (20202040) hasil downscaling model GCMs di lokasi penelitian dibandingkan dengan data baselinenya. Hasilnya seperti terlihat pada Gambar 4, dimana semua model GCMs menunjukan terjadi peningkatan suhu udara maksimum dengan besaran persentase yang bervariasi antara $2.5-6.0 \%$ di wilayah dataran tinggi dan 2.0-3.7\% di wilayah dataran rendah pada lokasi penelitian. Model MRI-CGCM3 menunjukan 
prosentase perubahan terendah diikuti model MIROC-ESM. Sedangkan prosentase perubahan tertinggi hasil dari model MIROCESM-CHEM diikuti MPI-ESM-LR dan MPIESM-MR. Secara umum dari keseluruhan model menunjukan bahwa wilayah dataran tinggi akan mengalami peningkatan suhu udara maksimum rata-rata sekitar $3.6 \%$ sedangkan di wilayah dataran rendah sebesar $2.4 \%$.

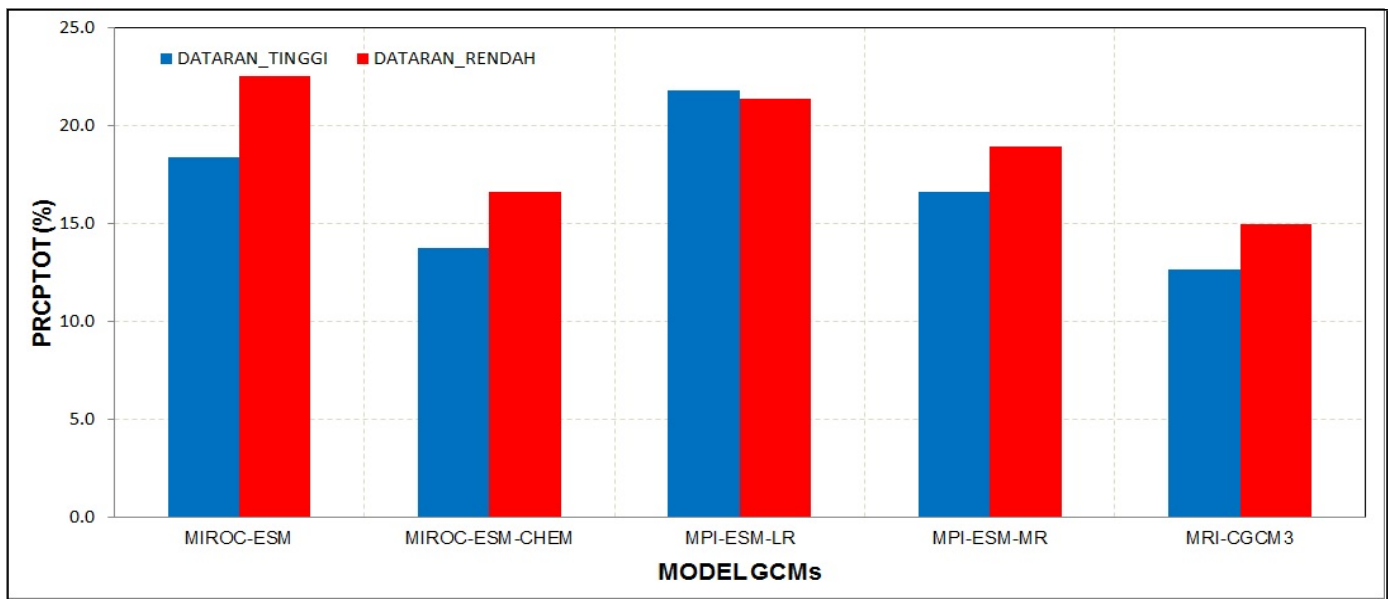

Gambar 3. Jumlah curah hujan tahunan (PRCPTOT) hasil proyeksi model GCMs dibandingkan baseline, di wilayah dataran tinggi dan dataran rendah pada lokasi penelitian.

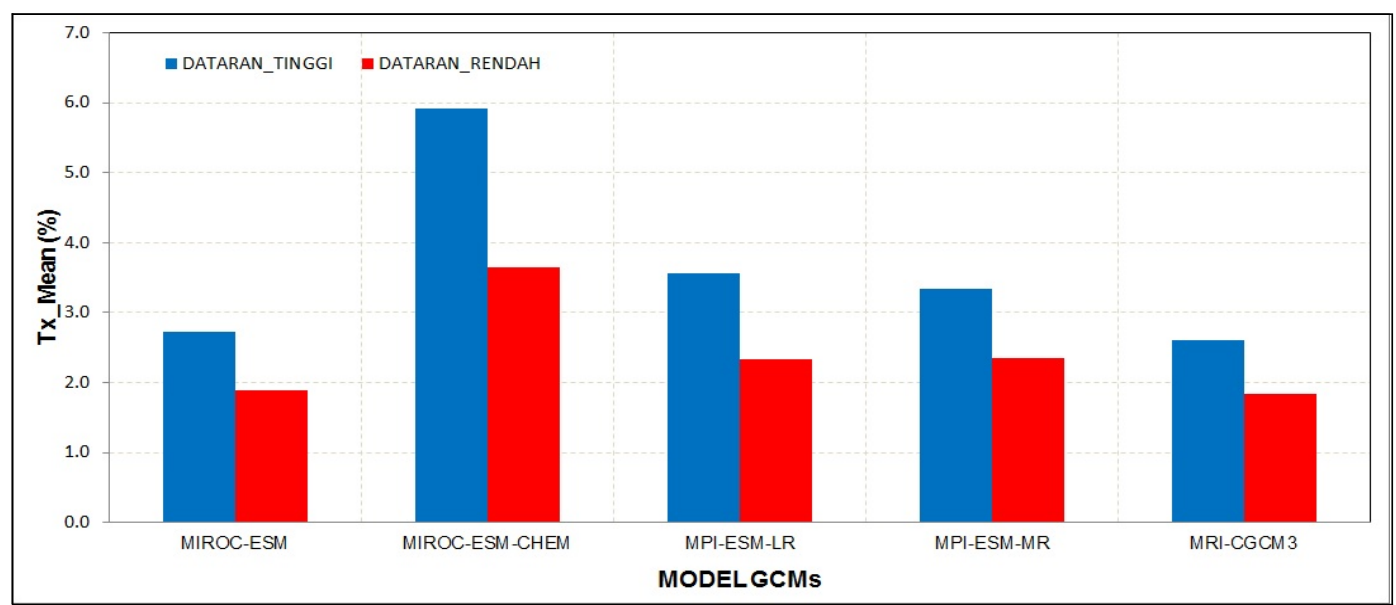

Gambar 4. Suhu udara maksimum rata-rata hasil proyeksi model GCMs dibandingkan baseline, di wilayah dataran tinggi dan dataran rendah pada lokasi penelitian.

Persentase perubahan suhu udara maksimum, merupakan rata-rata suhu udara maksimum tahunan pada tahun proyeksi (20202040) hasil downscaling model GCMs di lokasi penelitian dibandingkan dengan data baselinenya. Hasilnya seperti terlihat pada Gambar 4, dimana semua model GCMs menunjukan terjadi peningkatan suhu udara maksimum dengan besaran persentase yang bervariasi antara $2.5-6.0 \%$ di wilayah dataran tinggi dan 2.0-3.7\% di wilayah dataran rendah pada lokasi penelitian. Model MRI-CGCM3 menunjukan prosentase perubahan terendah diikuti model MIROC-ESM. Sedangkan prosentase perubahan tertinggi hasil dari model MIROCESM-CHEM diikuti MPI-ESM-LR dan MPIESM-MR. Secara umum dari keseluruhan model menunjukan bahwa wilayah dataran 
tinggi akan mengalami peningkatan suhu udara maksimum rata-rata sekitar $3.6 \%$ sedangkan di wilayah dataran rendah sebesar $2.4 \%$.

Persentase perubahan suhu udara minimum, merupakan rata-rata suhu udara minimum tahunan pada tahun proyeksi (20202040) hasil downscaling model GCMs di lokasi penelitian dibandingkan dengan data baselinenya. Hasilnya seperti terlihat pada Gambar 5, dimana semua model GCMs menunjukan terjadi peningkatan suhu udara minimum dengan besaran persentase yang bervariasi antara 4.6-8.0\% di wilayah dataran tinggi dan $3.8-7.0 \%$ di wilayah dataran rendah pada lokasi penelitian. Model MRI-CGCM3 menunjukan prosentase perubahan terendah diikuti model MPI-ESM-LR dan MPI-ESM-MR. Sedangkan prosentase perubahan tertinggi hasil dari model MIROC-ESM dan MIROC-ESMCHEM.Secara umum dari keseluruhan model menunjukan bahwa wilayah dataran tinggi akan mengalami peningkatan suhu udara maksimum rata-rata sekitar $6.2 \%$ sedangkan di wilayah dataran rendah sebesar 5.2\%.

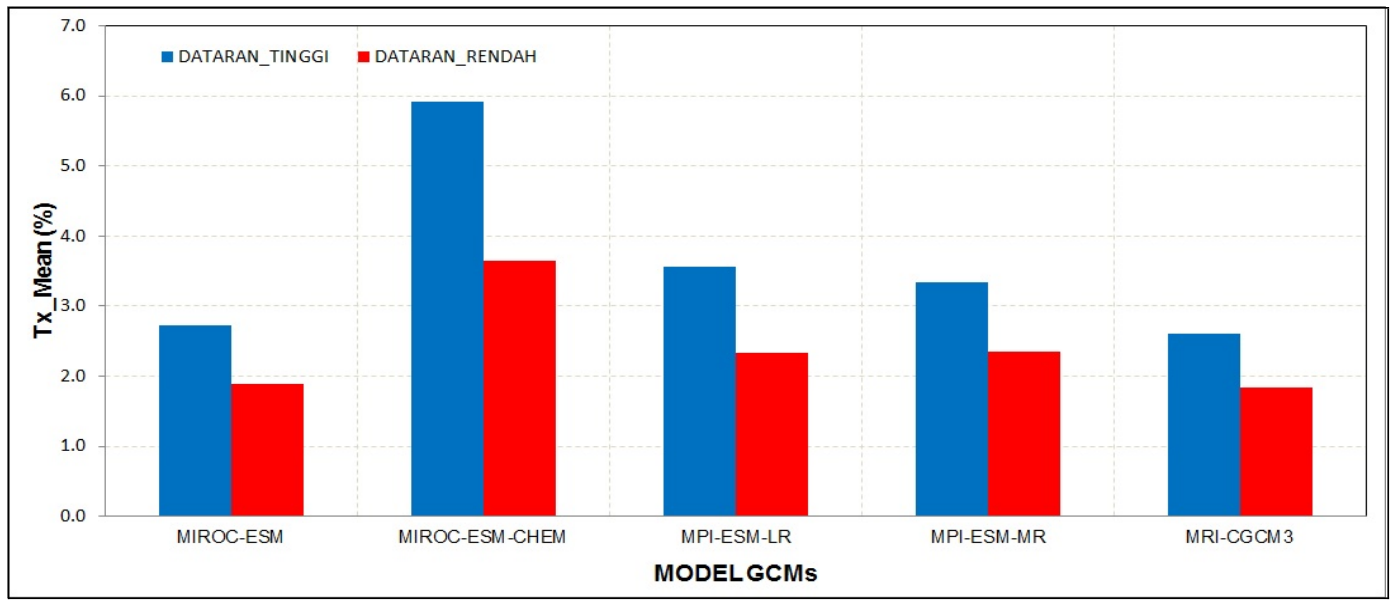

Gambar 4. Suhu udara maksimum rata-rata hasil proyeksi model GCMs dibandingkan baseline, di wilayah dataran tinggi dan dataran rendah pada lokasi penelitian.

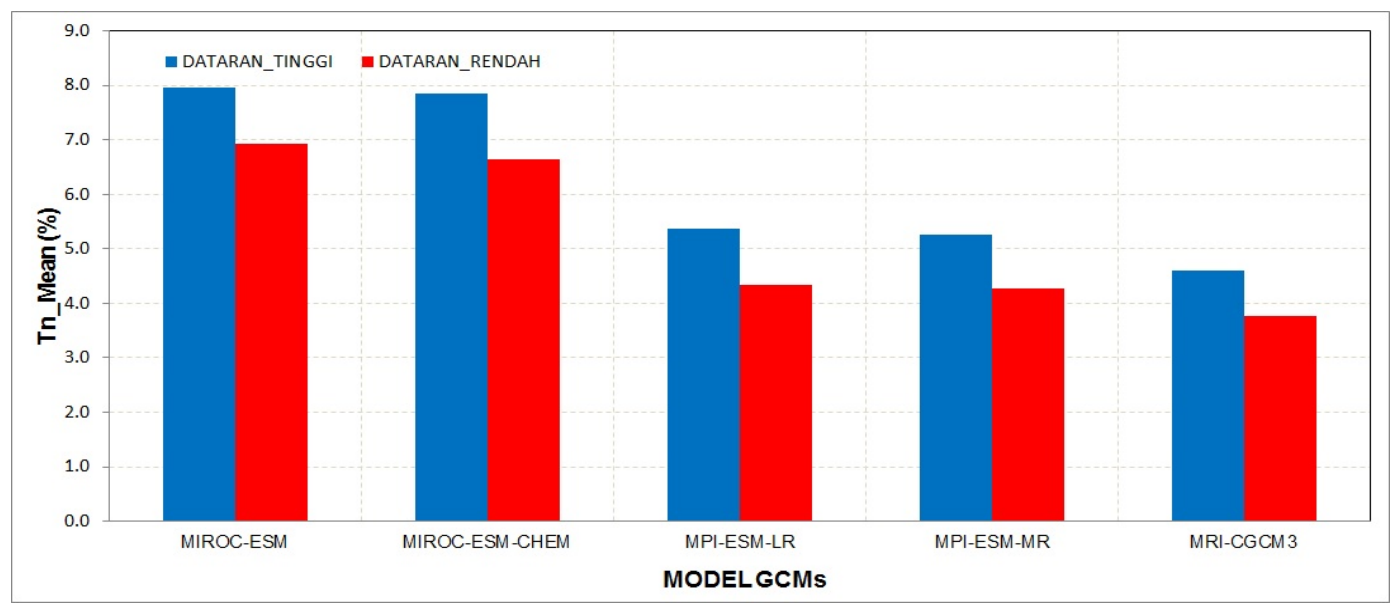

Gambar 5. Suhu udara maksimum rata-rata hasil proyeksi model GCMs dibandingkan baseline, di wilayah dataran tinggi dan dataran rendah pada lokasi penelitian. 


\subsection{Hasil Uji Bias Koreksi (CDFDM)}

1.5.1. Curah Hujan (Pr)

a) PBIAS

Seperti yang telah didefinisikan, bias merupakan indikator besaran penyimpangan atau perbedaan antara data yang belum dan sesudah dikoreksi. Gambar 6a menunjukan besarnya nilai bias curah hujan dari model GCMs di wilayah dataran tinggi dan wilayah dataran rendah pada wilayah penelitian. Nama model GCMs yang diawali dengan BC (Bias Correction), menunjukan bahwa pada model GCMs tersebut telah dilakukan $\mathrm{BC}$ dengan metode CDFDM. Gambar 4a berhubungan dengan Gambar 6b, yang memperlihatkan besarnya perubahan nilai bias (\%) curah hujan model GCMs sebelum dikoreksi dan setelah dikoreksi.

Pada Gambar 6a, terlihat nilai bias curah hujan di wilayah dataran tinggi berkisar antara $-0.74 \%-0.98 \%$, dengan nilai bias terkecil hasil model MPI-ESM-MR dan MIROC-ESMCHME, masing-masing dengan nilai bias $0.12 \%$ dan $-0.13 \%$. Nilai bias tertinggi merupakan hasil data model MIROC_ESM, MRI-CGCM3 dan MPI-ESM-LR. Di wilayah dataran tinggi, curah hujan mempunyai nilai bias yang lebih besar dibandingkan di wilayah dataran rendah, dengan nilai bias antara $-0.71 \%$ hingga $-1.68 \%$, dengan nilai bias terkecil hasil model MPI-ESM-LR dan MPI-ESM-MR, dengan nilai bias masing-masing sebesar $0.71 \%$ dan $-0.78 \%$. Nilai bias tertinggi merupakan hasil data model MRI-CGCM3, diikuti MIROC-ESM-CHEM dan MIROCESM. Nilai bias curah hujan di wilayah daerah dataran tinggi mempunyai nilai negative, mengindikasikan nilai observasi yang lebih besar nilainya dibandingkan nilai curah hujan hasil data model GCMs.

Pada Gambar 6a juga dapat dilihat data model yang telah mengalami $\mathrm{BC}$ (nama data model diawali dengan $\mathrm{BC}$ ). $\mathrm{BC}$ yang dilakukan mengakibatkan nilai prosentase bias curah hujan menjadi lebih besar dan secara keseluruhan mempunyai nilai positive, baik nilai bias di wilayah dataran tinggi maupun dataran rendah. Di wilayah dataran rendah, BC menyebabkan nilai bias curah hujan menjadi lima kali lipat dibandingan nilai bias sebelum dilakukan koreksi. Sementara di wilayah dataran tinggi, nilai bias menjadi tiga kali lipat sebelum dilakukan koreksi.

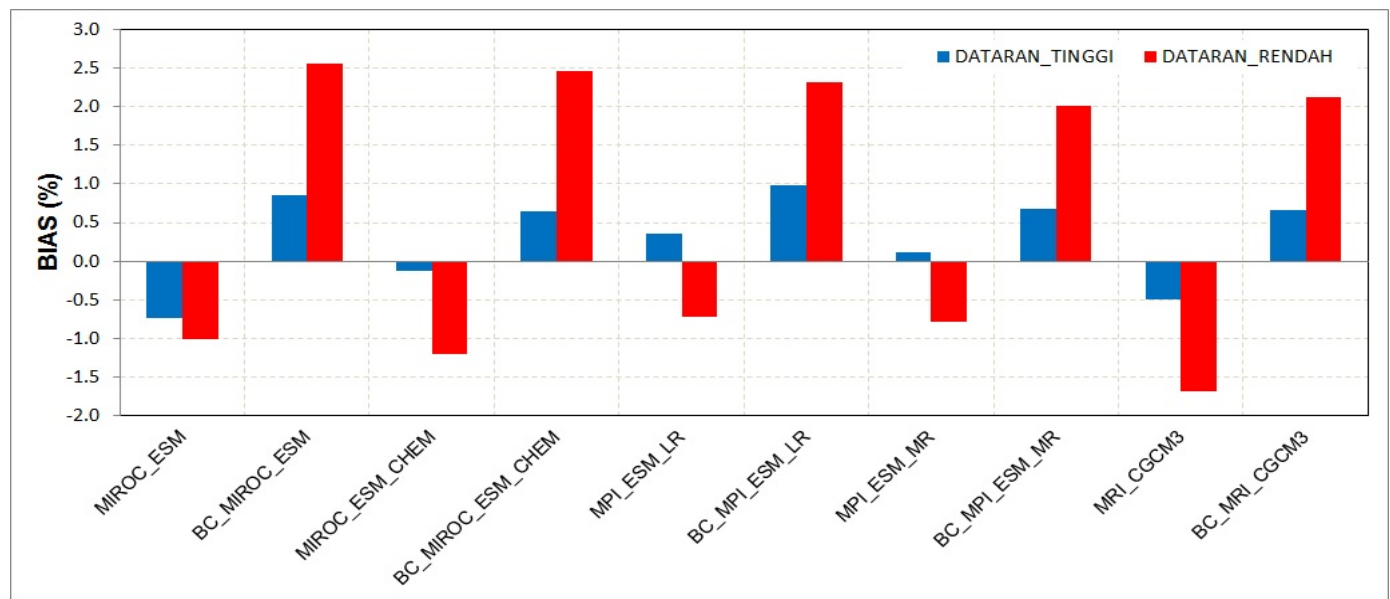

Gambar 6a. Besar nilai BIAS curah hujan (\%) data model GCMs dan observasi di wilayah dataran tinggi dan rendah pada lokasi penelitian. 


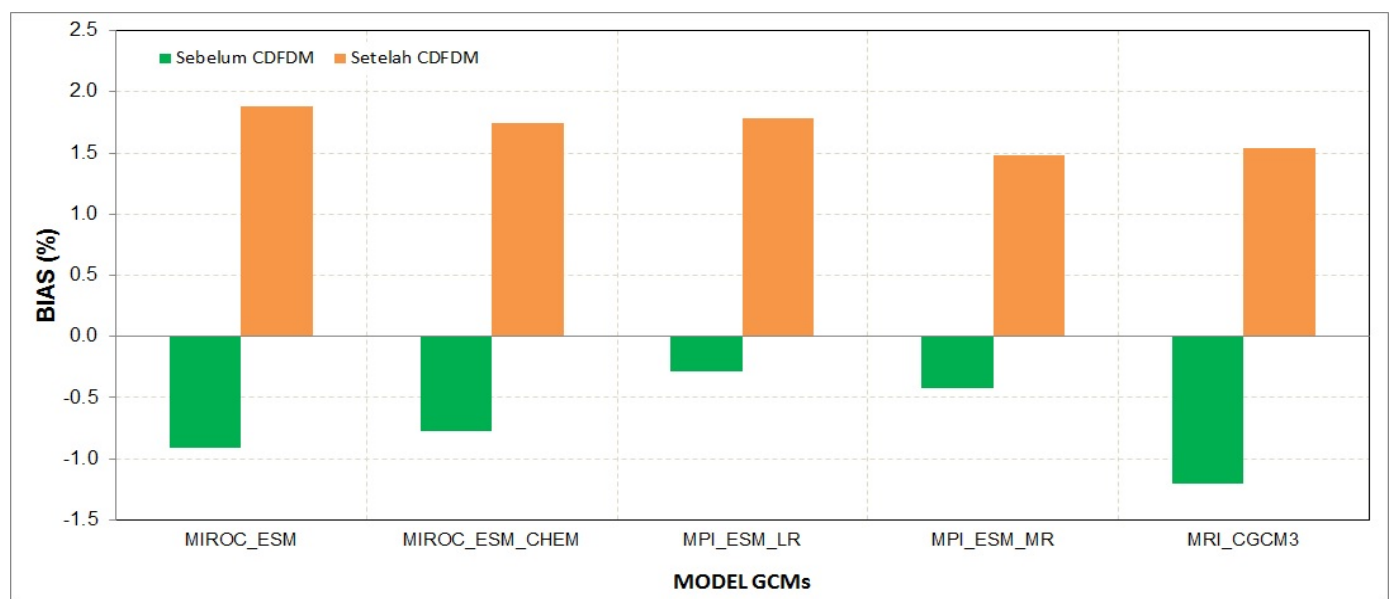

Gambar 6b. Perubahan nilai BIAS curah hujan (\%), sebelum dan setelah dilakukan koreksi bias metode CDFDM data model GCMs di lokasi penelitian.

Nilai bias hasil koreksi secara keseluruhan lebih jelas terlihat pada Gambar 6b, dimana nilai bias dari model sebelum dilakukan koreksi bias (CDFDM), sebesar $-0.29 \%$ hingga $-0.91 \%$, dengan nilai bias terkecil hasil model MPI-ESM-LR dan MPI-ESM-MR, masingmasing dengan nilai bias sebesar $-0.29 \%$ dan $0.42 \%$ namun setelah dilakukan $\mathrm{BC}$, nilai bias masing-masing menjadi $1.78 \%$ dan $1.74 \%$ atau naik menjadi sebesar tujuh dan tiga kali lipat sebelum dilakukan koreksi bias.

\section{b) $M A E$}

Hasil perhitungan MAE data curah hujan model GCMs di lokasi penelitin seperti yang ada pada Gambar 7a menunjukan nilai MAE curah hujan di wilayah dataran tinggi lebih kecil dibandingkan nilai MAE curah hujan di wilayah dataran rendah. Nilai MAE curah hujan di wilayah dataran berkisar antara 10.6$11.5 \mathrm{~mm} /$ hari. Sedangkan di wilayah dataran tinggi, nilai MAE curah hujan berkisar antara 14.5-15.6 mm/hari. Nilai MAE curah hujan terendah merupakan data hasil model MIROCESM-CHEM dan MIROC-ESM, dengan nilai masing-masing sebesar $10.62 \mathrm{~mm} /$ hari dan $10.65 \mathrm{~mm} /$ hari di wilayah dataran tinggi dan sebesar $14.53 \mathrm{~mm} /$ hari dan $14.55 \mathrm{~mm} /$ hari di wilayah dataran rendah.
Seperti halnya BC pada nilai bias yang memperbesar prosentase nilai bias, $\mathrm{BC}$ yang dilakukan juga mengakibatkan nilai MAE curah hujan menjadi lebih besar, baik nilai MAE di wilayah dataran tinggi maupun dataran rendah. Di wilayah dataran rendah, BC menyebabkan nilai MAE curah hujan meningkat sekitar 35\% dibandingan nilai MAE sebelum dilakukan koreksi. Sementara di wilayah dataran tinggi, nilai MAE curah hujan meningkat sekitar $18 \%$ dibandingkan sebelum dilakukan koreksi.

Secara keseluruhan, perubahan nilai MAE curah hujan sebelum dan setelah dilakukan koreksi, seperti terlihat pada Gambar 7b, dimana nilai MAE curah hujan dari data model sebelum dilakukan koreksi bias, sebesar 12.97$13.94 \mathrm{~mm} /$ hari, dengan nilai MAE terkecil hasil model MPI-ESM-LR dan MPI-ESM-MR, masing-masing dengan nilai MAE sebesar $12.97 \mathrm{~mm} /$ hari dan $13.00 \mathrm{~mm} /$ hari. Nilai MAE setelah dilakukan $\mathrm{BC}$, masing-masing menjadi nilai bias masing-masing menjadi 17.28 $\mathrm{mm} /$ hari dan $17.62 \mathrm{~mm} /$ hari atau meningkat nilainya menjadi sebesar $33 \%$ dan $36 \%$ dibandingkan nilai MAE sebelum dilakukan koreksi bias. 


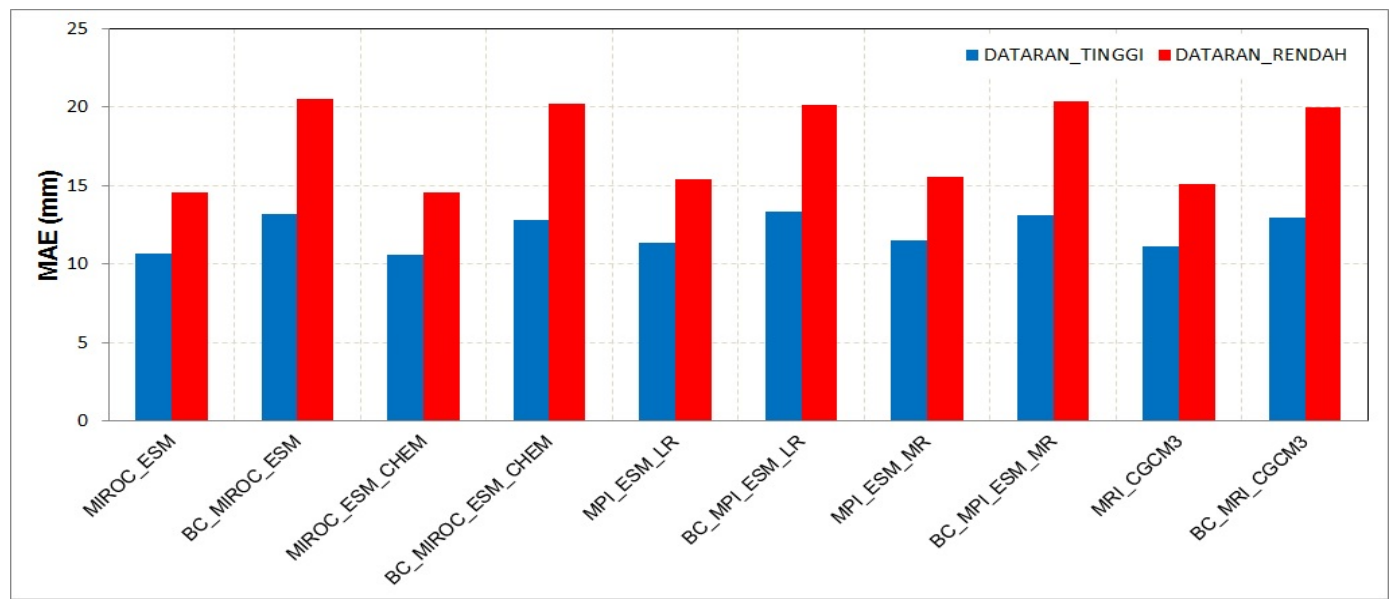

Gambar 7a. Besar nilai MAE curah hujan (mm) data model GCMs dan observasi di wilayah dataran tinggi dan rendah pada lokasi penelitian.

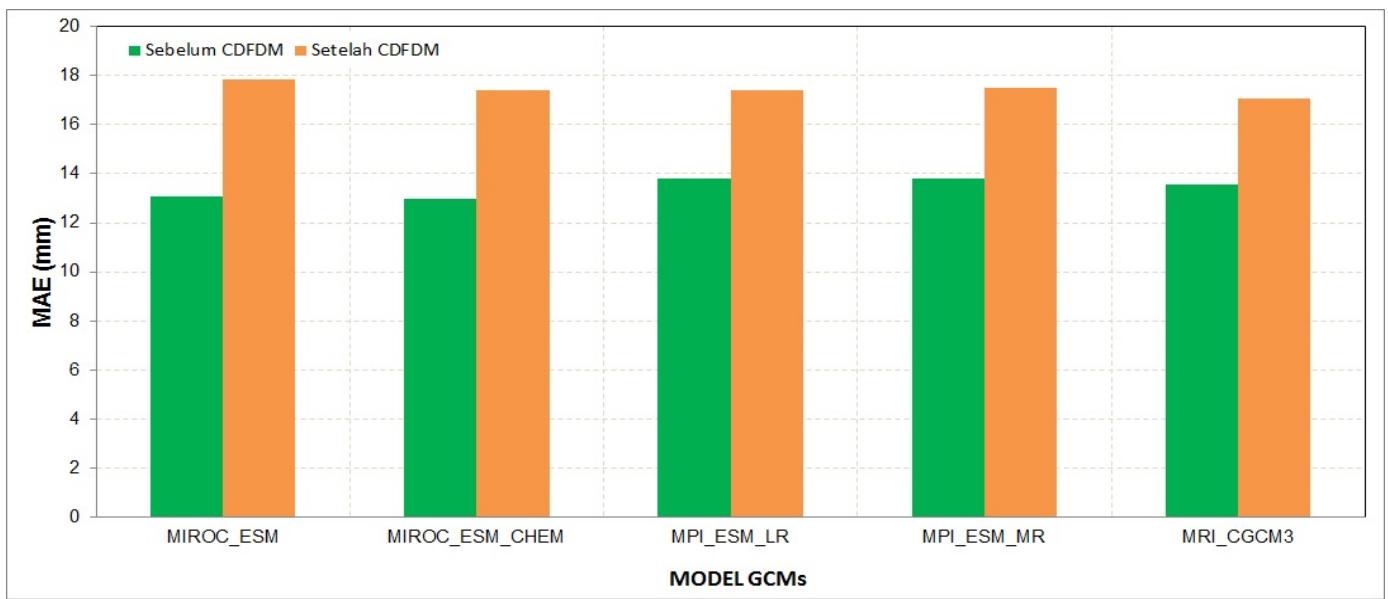

Gambar 7b. Perubahan nilai MAE curah hujan (mm), sebelum dan setelah dilakukan koreksi bias metode CDFDM data model GCMs di lokasi penelitian.

Secara keseluruhan, perubahan nilai MAE curah hujan sebelum dan setelah dilakukan koreksi, seperti terlihat pada Gambar 7b, dimana nilai MAE curah hujan dari data model sebelum dilakukan koreksi bias, sebesar 12.97$13.94 \mathrm{~mm} /$ hari, dengan nilai MAE terkecil hasil model MPI-ESM-LR dan MPI-ESM-MR, masing-masing dengan nilai MAE sebesar $12.97 \mathrm{~mm} /$ hari dan $13.00 \mathrm{~mm} /$ hari. Nilai MAE setelah dilakukan $\mathrm{BC}$, masing-masing menjadi nilai bias masing-masing menjadi 17.28 $\mathrm{mm} /$ hari dan $17.62 \mathrm{~mm} /$ hari atau meningkat nilainya menjadi sebesar $33 \%$ dan $36 \%$ dibandingkan nilai MAE sebelum dilakukan koreksi bias. c) RMSE

Pada Gambar 8a ditunjukan hasil perhitungan nilai RMSE curah hujan hasil model GCMs dan data observasi di lokasi penelitian. Pada gambar tesebut terlihat bahwa nilai RMSE curah hujan di daerah dataran tinggi lebih rendah jika dibandingkan nilai RMSE curah hujan di wilayah dataran rendah. Nilai RMSE curah hujan di wilayah dataran tinggi berkisar antara 16.58-18.22 $\mathrm{mm} / \mathrm{hari}$. Sedangkan di wilayah dataran rendah nilai RMSE curah hujan berkisar antara 24.73-26.34 mm/hari. Nilai RMSE curah hujan terendah merupakan data hasil model MIROC-ESM-CHEM dan MIROC-ESM, dengan nilai masing-masing sebesar $16.58 \mathrm{~mm} /$ hari dan $17.91 \mathrm{~mm} /$ hari di 
wilayah dataran tinggi, sedangkan model lainnya mempunyai nilai RMSE sekitar 18.10 $\mathrm{mm} /$ hari. Di wilayah dataran rendah, model MIROC-ESM-CHEM dan MIROC-ESM juga mempunyai nilai RMSE curah hujan terendah, masing-masing sebesar $24.73 \mathrm{~mm} /$ hari dan 24.86. Sedangkan model yang lain mempunyai nilai RMSE sekitar $26.20 \mathrm{~mm} / \mathrm{hari}$.

Sama halnya perlakuan BC pada BIAS dan MAE yang memperbesar prosentase nilai bias dan MAE, BC yang dilakukan juga mengakibatkan terjadinya peningkatan nilai RMSE curah hujan, baik nilai RMSE di wilayah dataran tinggi maupun dataran rendah. Di wilayah dataran rendah, BC menyebabkan nilai RMSE curah hujan meningkat sekitar 64\% dibandingan nilai RMSE sebelum dilakukan koreksi. Sementara di wilayah dataran tinggi, nilai RMSE curah hujan meningkat sekitar 34\% dibandingkan sebelum dilakukan koreksi.

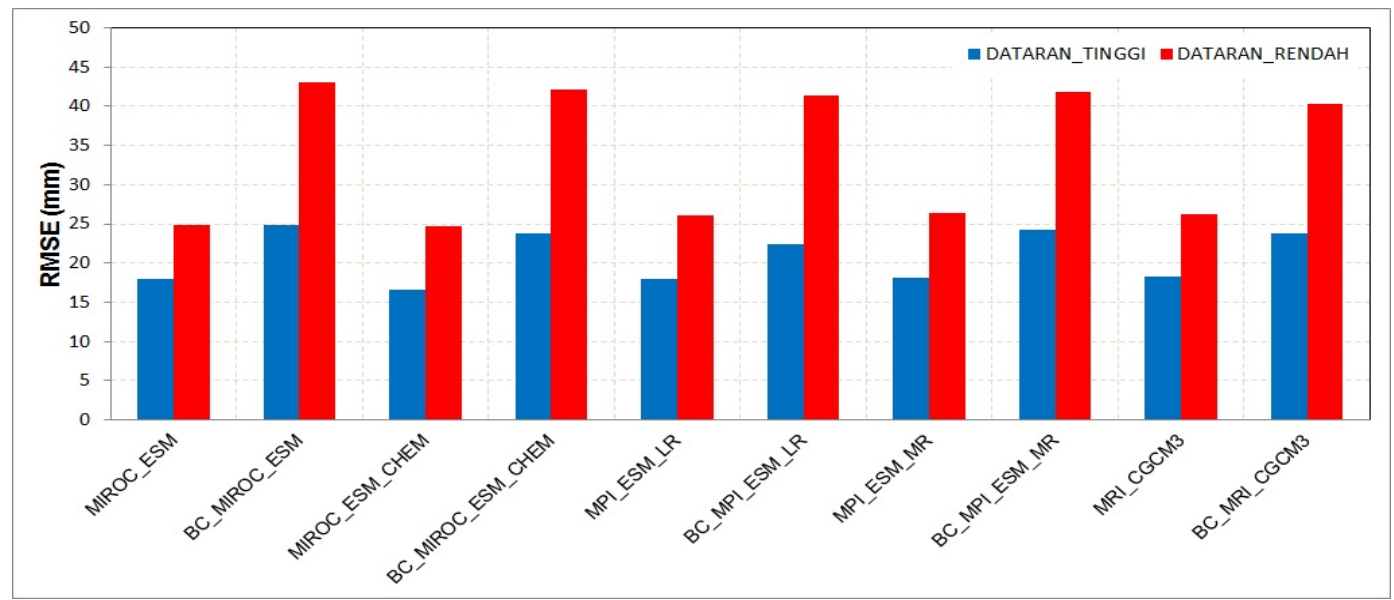

Gambar 8a. Besar nilai RMSE curah hujan (mm) data model GCMs dan observasi di wilayah dataran tinggi dan rendah pada lokasi penelitian.

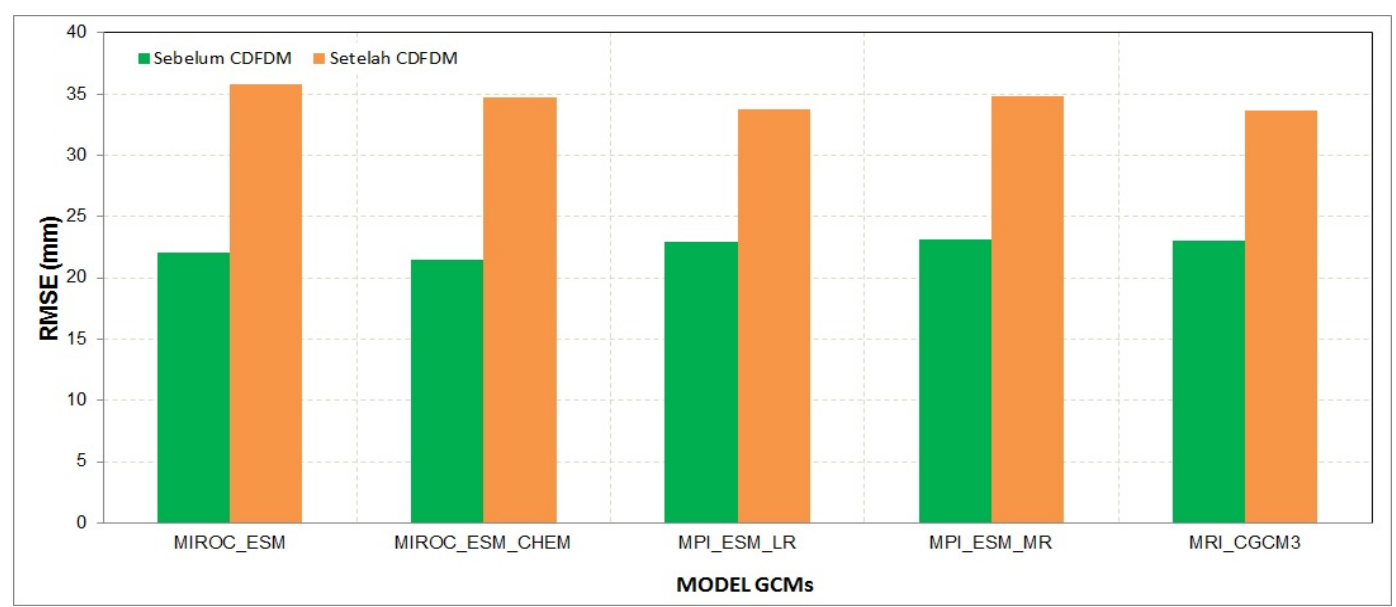

Gambar 8b. Perubahan nilai RMSE curah hujan (mm), sebelum dan setelah dilakukan koreksi bias metode CDFDM data model GCMs di lokasi penelitian.

Secara keseluruhan, perubahan nilai RMSE curah hujan sebelum dan setelah dilakukan koreksi, seperti terlihat pada Gambar 8 b, dimana nilai RMSE curah hujan dari data model sebelum dilakukan koreksi bias, sebesar 21.47-23.08 mm/hari, dengan nilai MAE terkecil hasil model MIROC-ESM-CHEM dan MIROC-ESM, masing-masing dengan nilai 
RMSE sebesar $21.47 \mathrm{~mm} / \mathrm{hari}$ dan 22.08 $\mathrm{mm} /$ hari. Nilai RMSE setelah dilakukan BC, masing-masing menjadi nilai bias masingmasing menjadi $34.76 \mathrm{~mm} / \mathrm{hari}$ dan 35.79 $\mathrm{mm} / \mathrm{hari}$ atau mengalami peningkatan nilai sebesar 62\% dibandingkan nilai RMSE sebelum dilakukan koreksi bias.

\subsubsection{Suhu Udara Maksimum (Tx)}

a) PBIAS

Hasil perhitungan nilai bias suhu udara maksimum rata-rata dapat dilihat pada Gambar 9a, dimana pada gambar tersebut nampak jelas terlihat perbedaan nilai bias suhu udara maksimum di wilayah dataran tinggi dan wilayah dataran rendah. Nilai bias suhu udara maksimum di wilayah dataran tinggi berkisar antara 2.44\%-2.83\%, dengan nilai bias terkecil hasil model MIROC-ESM-CHEM diikuti oleh model MIROC-ESM dan MRI-CGCM3 dengan nilai bias masing-masing sebesar $2.44 \%, 2.48 \%$ dan $2.50 \%$. Nilai bias tertinggi di wilayah dataran ini merupakan hasil data model MPI-ESM-LR dan MPI-ESM-MR, dengan nilai bias masing-masing sebesar $2.76 \%$ dan $2.83 \%$. Di wilayah dataran rendah, suhu udara maksimum mempunyai nilai bias yang jauh lebih kecil dibandingkan di wilayah dataran tinggi, dengan nilai bias antara $0.32 \%$ hingga $0.59 \%$, dengan nilai bias terkecil hasil model MIROC-ESM-CHEM dan MIROCESM, dengan nilai bias masing-masing sebesar $0.319 \%$ dan $0.325 \%$. Sedangkan nilai bias suhu udara dari model yang lain di wilayah dataran rendah ini, secara rata-rata tidak lebih dari $0.45 \%$. Jika dibuat perbandingan, maka nilai bias suhu udara maksimum di wilayah dataran rendah hamper tujuh kali lipat lebih rendah nilai bias suhu udara maksimum di wilayah dataran tinggi.

Pada Gambar 9a juga dapat dilihat data model yang telah mengalami $\mathrm{BC}$, terlihat perlakuan BC pada data model GCMs secara signifikan dapat memperkecil nilai bias suhu udara maksimum, baik nilai bias di wilayah dataran tinggi maupun dataran rendah. Signifikansi penurunan nilai bias, seperti terlihat pada model MIROC-ESM dan MPIESM-LR, dengan nilai bias suhu udara maskimum di wilayah dataran tinggi hasil koreksi hamper mendekati $0.00 \%$ yang berarti nilai suhu udara maskimum hasil koreksi sama dengan nilai observasinya. Hal yang sama juga terlihat pada model MIROC-ESM-CHEM dan MPI-ESM-LR yang telah dikoreksi, dimana terlihat nilai bias untuk di wilayah dataran rendah, juga mendekati $0.00 \%$. Secara umum BC menyebabkan nilai bias suhu udara maksimum, baik di wilayah dataran tinggi maupun di wilayah dataran rendah nilai bias nya menjadi antara $0.03-0.26 \%$ berbeda cukup jauh dibnadingkan nilai bias suhu udara maksimum yang belum dikoreksi dengan nilai bias rata-rata $2.56 \%$ di wilayah dataran tinggi dan $0.38 \%$ untuk wilayah dataran rendah.

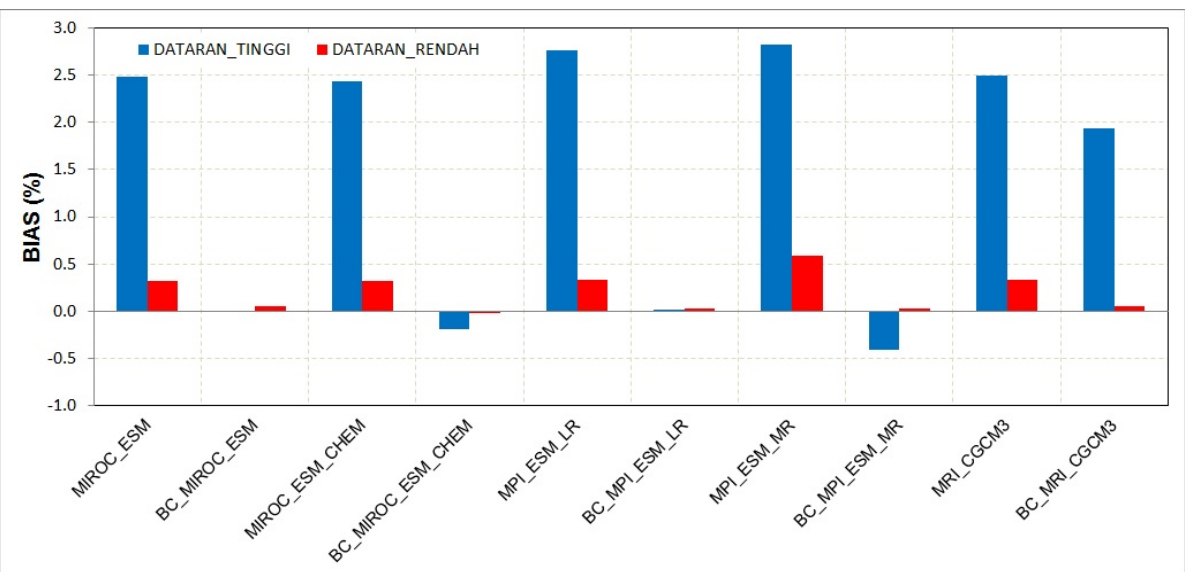

Gambar 9a. Besar nilai BIAS suhu udara maksimum (\%) data model GCMs dan observasi di wilayah dataran tinggi dan rendah pada lokasi penelitian. 
Nilai bias suhu udara maksimum hasil model GCMs yang telah koreksi secara jelas terlihat pada Gambar 9b, dimana nilai bias dari model sebelum dilakukan BC, sebesar $1.17 \%$ hingga $1.48 \%$, dengan nilai bias terkecil hasil model MIROC-ESM-CHEM diikuti oleh model MIROC-ESM dan MRI-CGCM3, masing-masing dengan nilai bias sebesar
$1.17 \%, 1.19 \%$ dan $1.20 \%$. Setelah dilakukan $\mathrm{BC}$, nilai bias menjadi jauh lebih kecil, yaitu sebesar $\quad 0.02 \%$ dan $0.03 \%$ masing-masing untuk model MPI-ESM-LR dan MIROC-ESM. Sedangkan nilai bias yang masih tetap tinggi setelah dilakukan BC adalah model MRICGCM3, yaitu sebesar $0.81 \%$ dari sebelumnya $1.19 \%$.

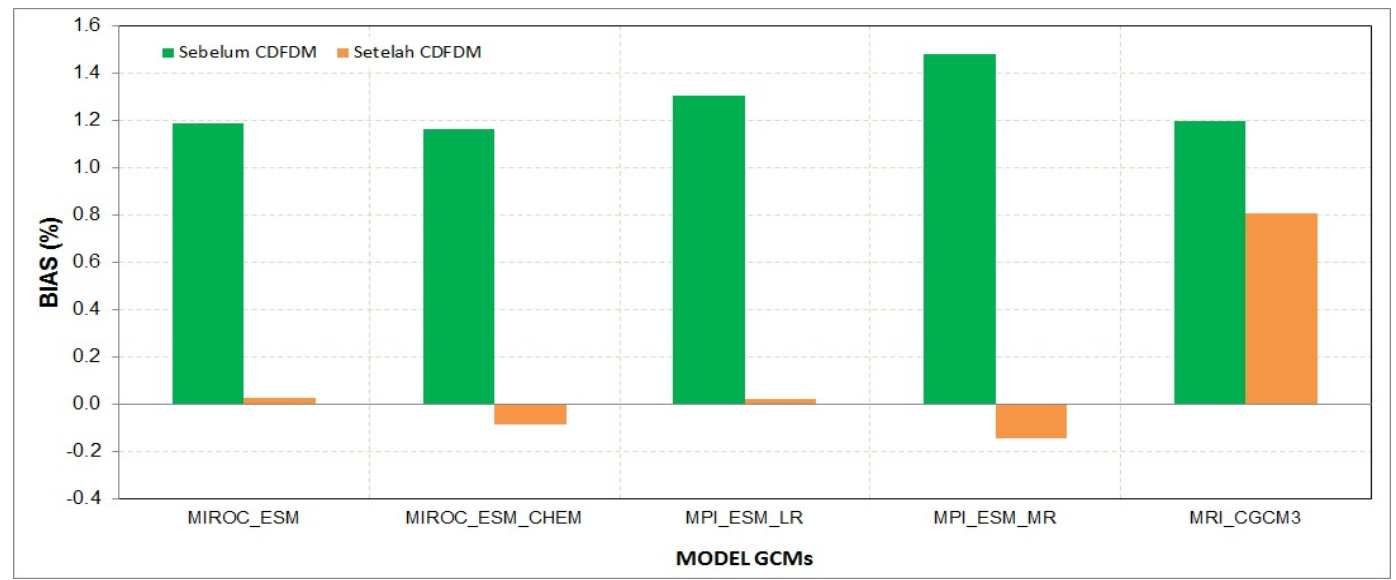

Gambar 9b. Perubahan nilai BIAS suhu udara maksimum (\%), sebelum dan setelah dilakukan koreksi bias metode CDFDM data model GCMs di lokasi penelitian.

\section{b) $M A E$}

Pada Gambar 10a terlihat grafi hasil perhitungan MAE untuk data suhu udara maksimum model GCMs di lokasi penelitian. Pada gambar tersebut terlihat nilai MAE suhu udara maksimum di wilayah dataran tinggi lebih besar dibandingkan nilai MAE suhu udara maksimum di wilayah dataran rendah. Nilai MAE suhu udara maksimum di wilayah dataran tinggi berkisar antara 2.60-2.96 ${ }^{\mathrm{O}} \mathrm{C} /$ hari. Sedangkan di wilayah dataran rendah, nilai MAE suhu udara maksimum berkisar antara 1.35-1.54 ${ }^{\circ} \mathrm{C} /$ hari. Nilai MAE suhu udara maksimum terendah merupakan data hasil model MIROC-ESM-CHEM dan MIROC-ESM, dengan nilai masing-masing sebesar $2.60{ }^{\circ} \mathrm{C} /$ hari dan $2.72{ }^{\circ} \mathrm{C} /$ hari di wilayah dataran tinggi dan sebesar $1.35^{\circ} \mathrm{C} /$ hari dan $1.44{ }^{\circ} \mathrm{C} /$ hari di wilayah dataran rendah.

Pada Gambar 10a dapat dilihat, perlakuan BC pada data suhu udara maksimum hasil model GCMs, mengakibatkan nilai MAE suhu udara maksimum yang bervariasi. Di wilayah dataran rendah, $\mathrm{BC}$ hamper tidak merubah nilai MAE, artinya nilai MAE di wilayah dataran rendah hamper sama sebelum dan setelah dilakukan BC. Sementara di wilayah dataran tinggi, $\mathrm{BC}$ menyebabkan nilai MAE menjadi lebih rendah, seperti yang terlihat pada model MIROC-ESM, MIROCESM-CHEM dan MPI-ESM-LR. Sedangkan pada model MPI-ESM-MR dan MRI-CGCM3, BC mengakibatkan nilai MAE suhu udara maksimum menjadi lebih tinggi. Pada kelompok model pertama, BC menyebabkan nilai MAE suhu udara maksimum mengalami penurunan sekitar $44 \%$ dibandingan nilai MAE sebelum dilakukan koreksi. Sementara pada kelompok model yang kedua, nilai MAE suhu udara maksimum meningkat sekitar 13\% dibandingkan sebelum dilakukan koreksi.

Perubahan nilai MAE suhu udara maksimum sebelum dan setelah dilakukan koreksi secara umum yang terjadi di lokasi penelitian, seperti terlihat pada Gambar 10b, dimana nilai MAE suhu udara maksimum pada model MIROC-ESM, MIROC-ESM-CHEM dan MPI-ESM-LR mengalami penurunan 
sebesar $16.5 \%$ setelah dilakukan koreksi bias. Sedangkan pada model MPI-ESM-MR dan MRI-CGCM3, BC mengakibatkan nilai MAE suhu udara maksimum mengalami peningkatan sebesar 5.5\% setelah dilakukan koreksi bias.

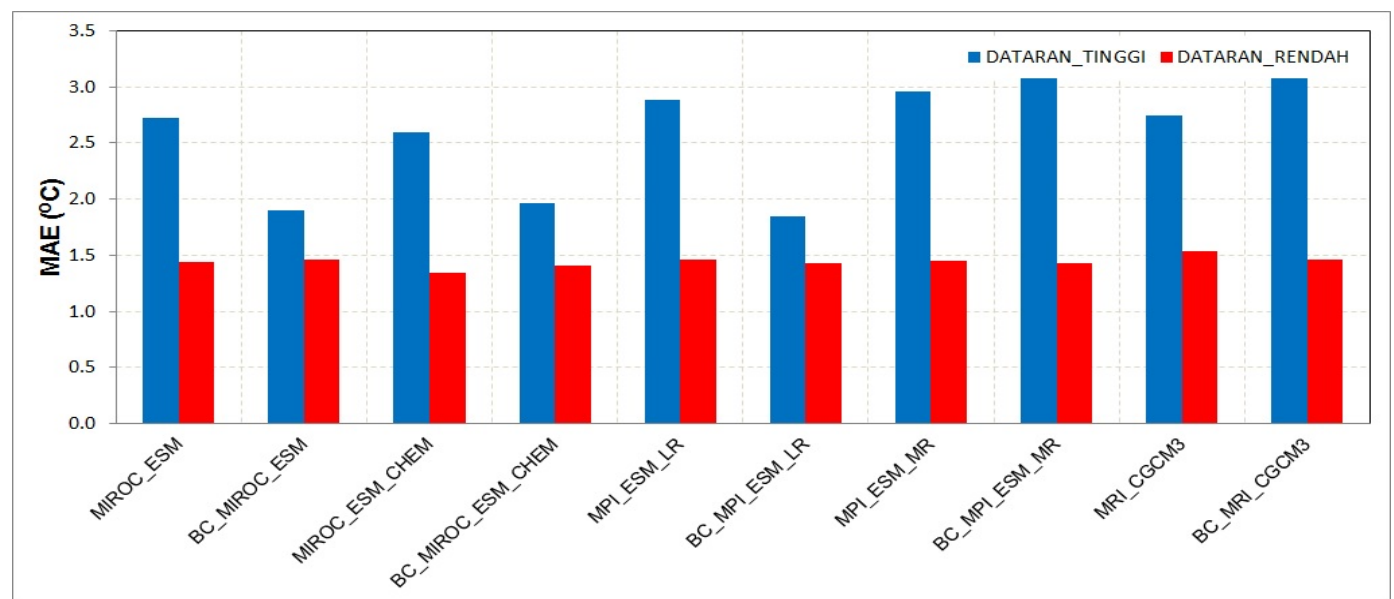

Gambar 10a. Besar nilai MAE suhu udara maksimum $\left({ }^{\circ} \mathrm{C}\right)$ data model GCMs dan observasi di wilayah dataran tinggi dan rendah pada lokasi penelitian.

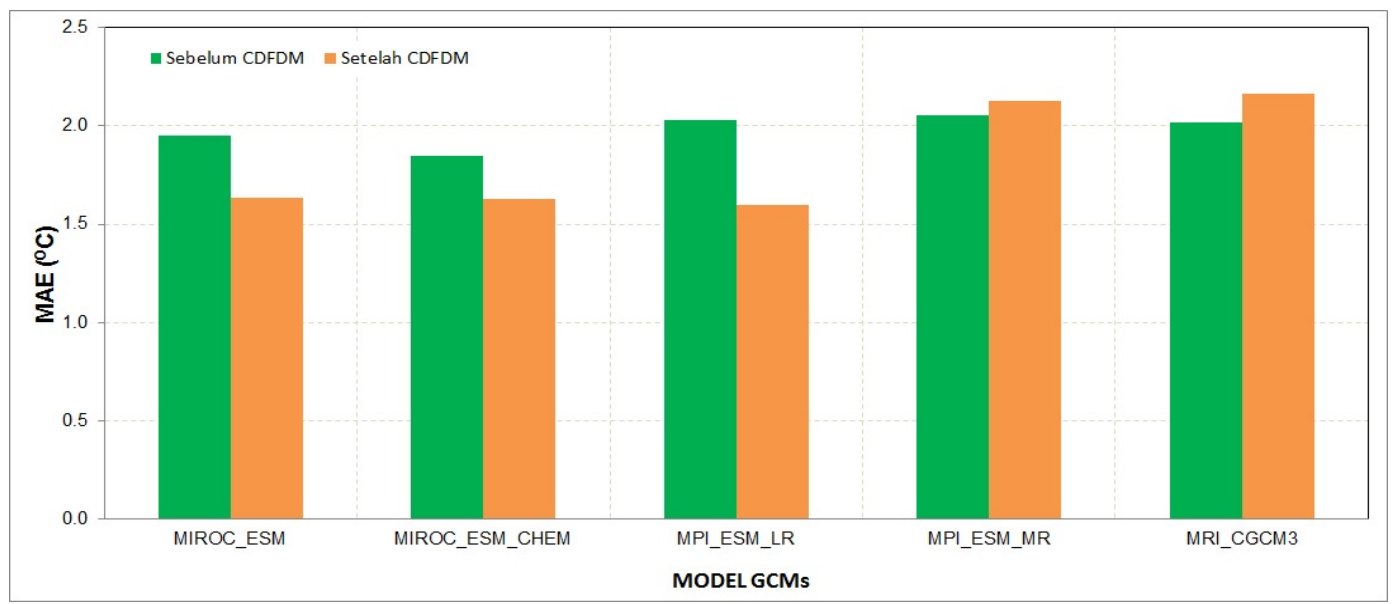

Gambar 10b. Perubahan nilai MAE suhu udara maksimum $\left({ }^{\circ} \mathrm{C}\right)$, sebelum dan setelah dilakukan koreksi bias metode CDFDM data model GCMs di lokasi penelitian.

\section{c) RMSE}

Pada Gambar 11a ditunjukan hasil perhitungan nilai RMSE suhu udara maksimum hasil model GCMs dan data observasi di lokasi penelitian. Pada gambar tersebut terlihat pola RMSE yang mirip dengan pola MAE data suhu maksimum, dimana nilai RMSE suhu udara maksimum di wilayah dataran tinggi lebih besar dibandingkan nilai RMSE suhu udara maksimum di wilayah dataran rendah. Nilai RMSE suhu udara maksimum di wilayah dataran tinggi berkisar antara 3.17-3.53
${ }^{\mathrm{O}} \mathrm{C} /$ hari. Sedangkan di wilayah dataran rendah, nilai MAE suhu udara maksimum berkisar antara 1.76-1.98 ${ }^{\circ} \mathrm{C} /$ hari. Nilai RMSE suhu udara maksimum terendah merupakan data hasil model MIROC-ESM-CHEM dan MIROC-ESM, dengan nilai masing-masing sebesar $3.17{ }^{\circ} \mathrm{C} /$ hari dan $3.35{ }^{\circ} \mathrm{C} /$ hari $\mathrm{di}$ wilayah dataran tinggi. Sedangkan di wilayah dataran rendah, nilai RMSE suhu udara maksimum terendah sebesar $1.35{ }^{\circ} \mathrm{C} /$ hari merupakan data hasil model MIROC-ESMCHEM. Model-model GCMs yang lain 
mempunyai nilai RMSE suhu udara maksimum lebih besar dari $1.80{ }^{\circ} \mathrm{C} /$ hari.

Koreksi bias yang dilakukan pada data suhu udara maksimum hasil model GCMs mengakibatkan nilai RMSE suhu udara maksimum yang bervariasi. Di wilayah dataran rendah, BC hampir tidak merubah nilai RMSE, artinya nilai RMSE di wilayah dataran rendah hampir sama sebelum dan setelah dilakukan $\mathrm{BC}$, rata-rata perubahan nilai RMSE hanya sekitar 2.98\% dari sebelum dan setelah dilakukan koreksi. Sementara di wilayah dataran tinggi, $\mathrm{BC}$ menyebabkan nilai RMSE menjadi lebih rendah sebesar $16.31 \%$, seperti yang terlihat pada model MIROC-ESM, MIROC-ESM-CHEM dan MPI-ESM-LR. Sedangkan pada model MPI-ESM-MR dan
MRI-CGCM3, BC mengakibatkan nilai RMSE suhu udara maksimum menjadi lebih tinggi atau paling tidak sama dengan nilai sebelum dilakukan koreksi.

Perubahan nilai RMSE suhu udara maksimum sebelum dan setelah dilakukan koreksi secara umum yang terjadi di lokasi penelitian, seperti terlihat pada Gambar 11b, dimana nilai RMSE suhu udara maksimum pada model MIROC-ESM, MIROC-ESMCHEM dan MPI-ESM-LR mengalami penurunan sebesar $21.0 \%$ setelah dilakukan koreksi bias. Sedangkan pada model MPIESM-MR dan MRI-CGCM3, perlakuan BC hampir tidak menyebakan perubahan nilai RMSE suhu udara maksimum.

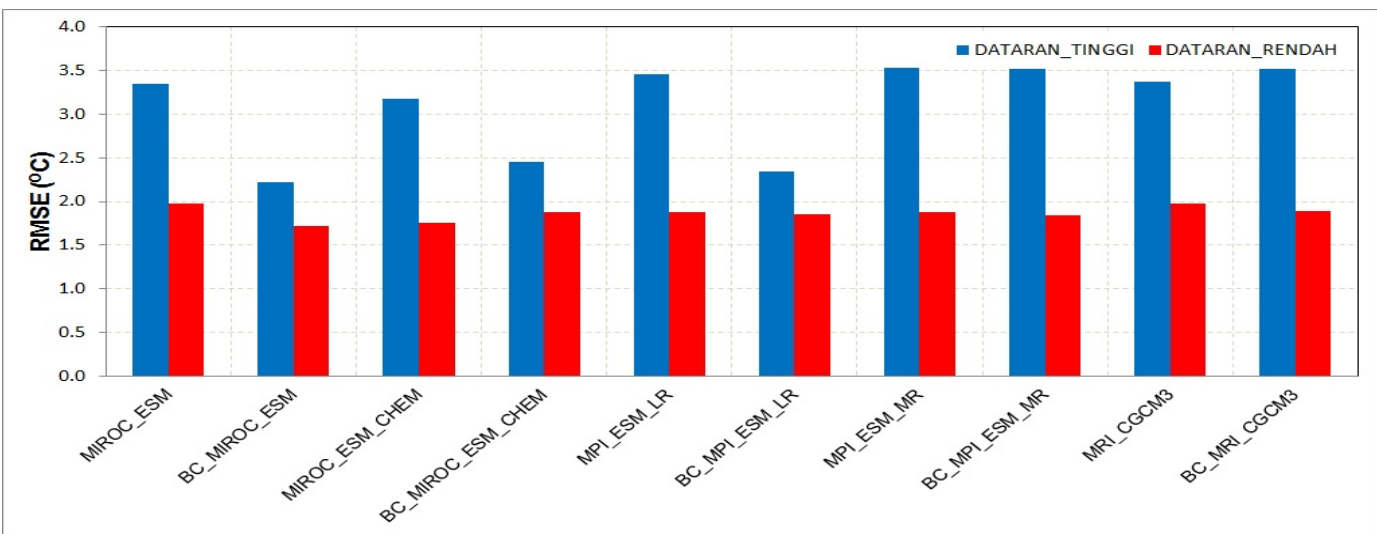

Gambar 11a. Besar nilai RMSE suhu udara maksimum $\left({ }^{\circ} \mathrm{C}\right)$ data model GCMs dan observasi di wilayah dataran tinggi dan rendah pada lokasi penelitian.

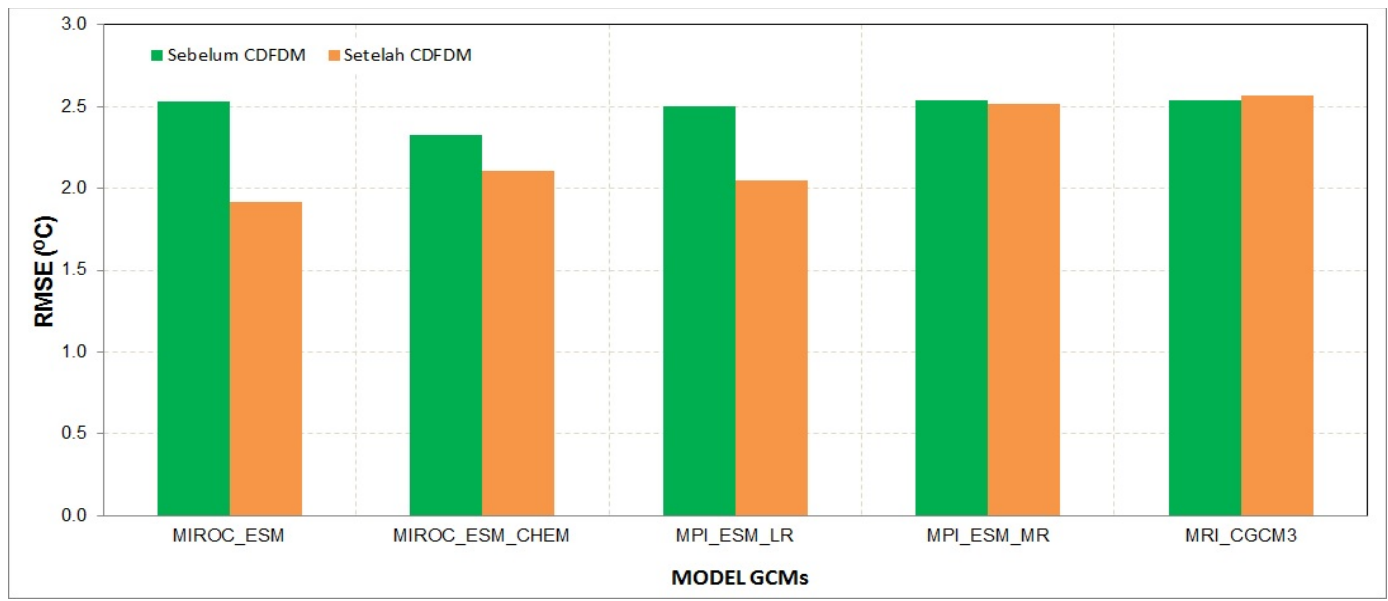

Gambar 11b. Perubahan nilai RMSE suhu udara maksimum $\left({ }^{\circ} \mathrm{C}\right)$, sebelum dan setelah dilakukan koreksi bias metode CDFDM data model GCMs di lokasi penelitian. 


\subsubsection{Suhu Udara Minimum (Tn)}

a) PBIAS

Pada Gambar 12a, terlihat grafik nilai bias suhu udara minimum dari data model GCMs di lokasi penelitian. Pada gambar tersebut terlihat keseluruhan model mempunyai nilai bias negative, baik di wilayah dataran tinggi maupun wilayah dataran rendah. Hal ini berarti, data suhu udara minimum dari model GCMs yang lebih rendah dari data observasi. Dari gambar tersebut juga jelas terlihat nilai bias suhu udara minimum di wiayah dataran tinggi mempunyai nilai yang lebih rendah jika dibandingkan nilai bias di wilayah dataran rendah.

Nilai bias suhu udara minimum di wilayah dataran tinggi berkisar antara $-0.56 \%$ hingga $0.89 \%$, dengan nilai bias terkecil hasil model MPI-ESM-LR diikuti oleh model MPI-ESMMR dengan nilai bias masing-masing sebesar $0.56 \%$ dan $-0.63 \%$. Nilai bias tertinggi di wilayah dataran ini merupakan hasil data model MRI-CGCM3 diikuti oleh model MIROC-ESM-CHEM dan MIROC-ESM, dengan nilai bias masing-masing sebesar $0.89 \%,-0.84 \%$ dan $-0.77 \%$. Di wilayah dataran rendah, suhu udara maksimum mempunyai nilai bias yang jauh lebih kecil dibandingkan di wilayah dataran tinggi, dengan nilai bias antara $-1.35 \%$ hingga $-1.64 \%$, dengan nilai bias terkecil hasil model MIROC-ESM-
CHEM dan MPI-ESM-MR, dengan nilai bias masing-masing sebesar $-1.359 \%$. Sedangkan nilai bias suhu udara minimum dari model yang lain di wilayah dataran rendah ini, secara rata-rata mencapai lebih dari $1.56 \%$. Pada gambar tersebut juga dapat dilihat, bahwa perlakuan BC pada data model GCMs secara signifikan dapat memperkecil nilai bias suhu udara minimum, baik nilai bias di wilayah dataran tinggi maupun dataran rendah. Signifikansi penurunan nilai bias, seperti terlihat pada model MPI-ESM-LR dan MPIESM-MR, dengan nilai bias suhu udara minimum sebesar $-0.02 \%$ dan $-0.01 \%$ masingmasing untuk nilai bias di wilayah dataran tinggi dan wilayah dataran rendah setelah dikoreksi. Nilai-nilai tersebut menunjukan bahwa nilai suhu udara minimum model yang telah dikoreksi hampir sama dengan nilai observasinya. Secara umum perlakuan BC menyebabkan nilai bias suhu udara minimum, baik di wilayah dataran tinggi dengan nilai bias antara $-0.04 \%$ hingga $-0.15 \%$ berbeda relativ jauh jika dibandingkan nilai bias suhu udara maksimum yang belum dikoreksi dengan nilai bias rata-rata $-0.74 \%$. Untuk wilayah dataran tinggi, perlakukan $\mathrm{BC}$ dapat menyebabkan penurunan nilai bias menjadi antara $-0.10 \%$ hingga $-0.12 \%$ berbeda cukup signifikan dengan nilai bias suhu udara minimum yang belum dikoreksi sebesar $-1.48 \%$.

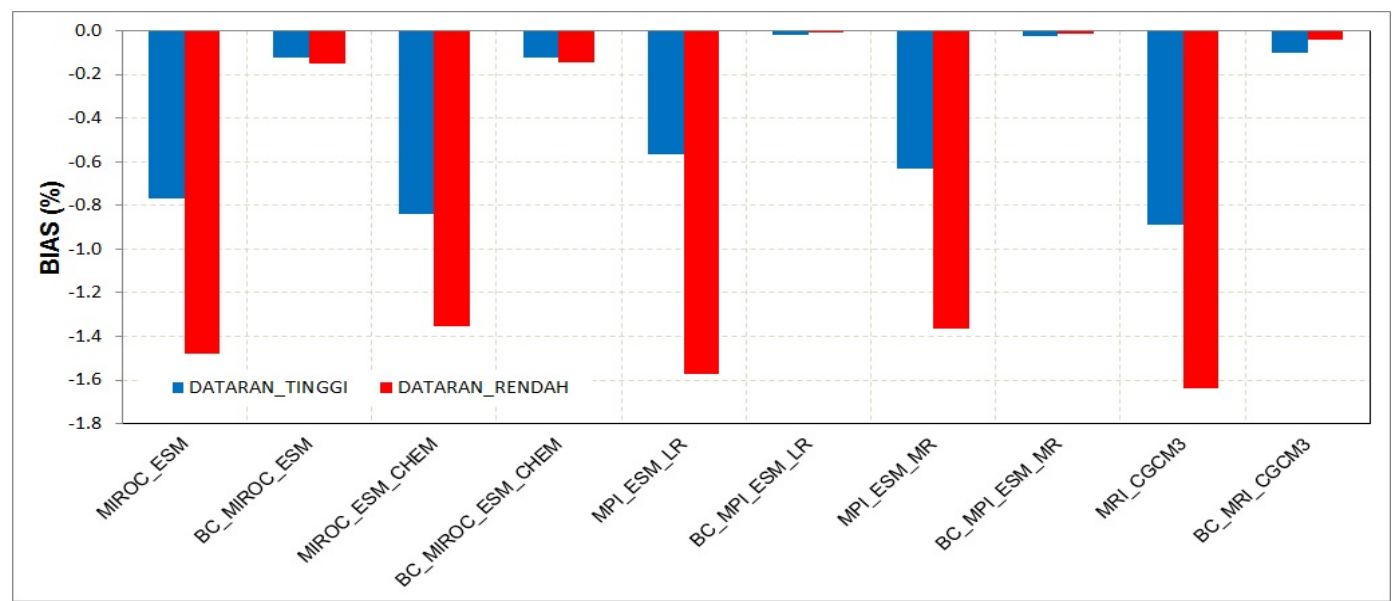

Gambar 12a. Besar nilai BIAS suhu udara minimum (\%) data model GCMs dan observasi di wilayah dataran tinggi dan rendah pada lokasi penelitian. 


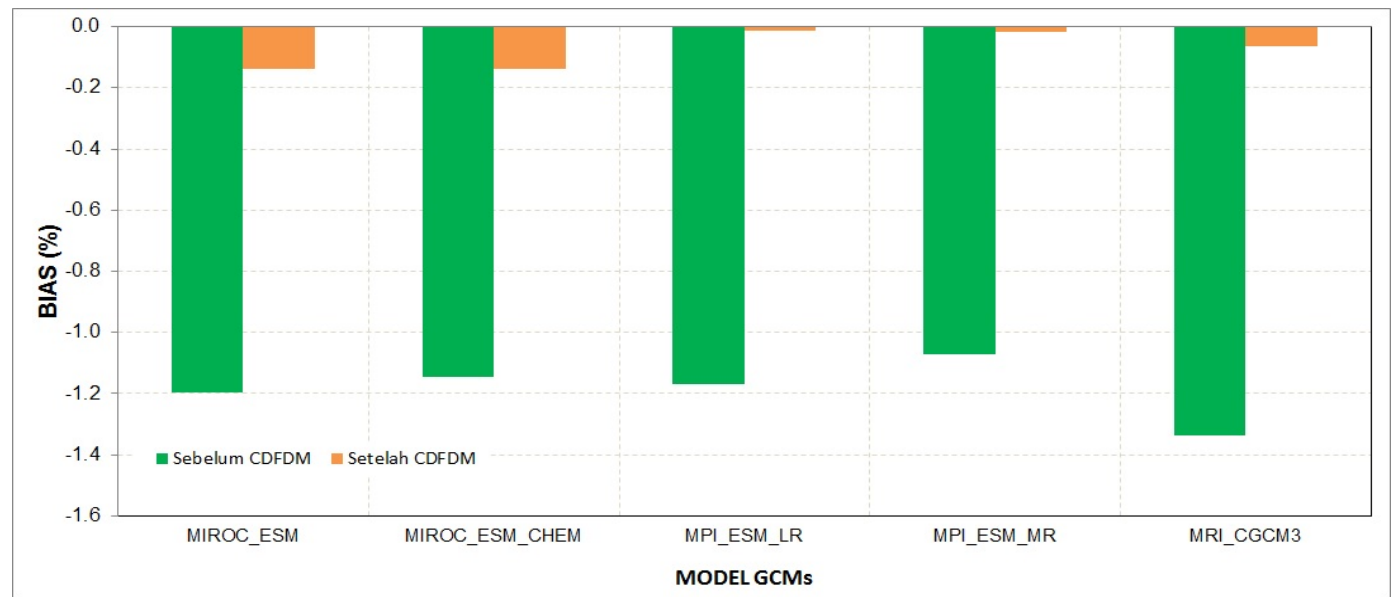

Gambar 12b. Perubahan nilai BIAS suhu udara minimum (\%), sebelum dan setelah dilakukan koreksi bias metode CDFDM data model GCMs di lokasi penelitian.

Nilai bias suhu udara minimum hasil model GCMs yang telah koreksi secara jelas terlihat pada Gambar 12b, dimana nilai bias dari model sebelum dilakukan $\mathrm{BC}$, sebesar $1.07 \%$ hingga $-1.34 \%$, dengan nilai bias terkecil hasil model MPI-ESM-MR diikuti oleh model MIROC-ESM-CHEM dan MPI-ESMLR, masing-masing dengan nilai bias sebesar $1.07 \%,-1.15 \%$ dan $-1.17 \%$. Setelah dilakukan $\mathrm{BC}$, nilai bias menjadi jauh lebih kecil, yaitu sebesar $-0.01 \%,-0.02 \%$ dan $-0.06 \%$ masingmasing untuk model MPI-ESM-LR, MPIESM-MR dan MRI-CGCM3. Sedangkan nilai bias suhu minimum untuk model lainya mempunyai nilai rata-rata sebesar $-0.14 \%$.

\section{b) $M A E$}

Hasil perhitungan MAE untuk data suhu udara maksimum model GCMs di lokasi penelitian seperti yang terlihat pada Gambar 13a menunjukan bahwa nilai MAE suhu udara minimum di wilayah dataran rendah mempunyai nilai yang lebih besar dibandingkan nilai MAE suhu udara minimum di wilayah dataran tinggi. Nilai MAE suhu udara minimum di wilayah dataran tinggi berkisar antara $1.17-1.51{ }^{\circ} \mathrm{C} /$ hari. Sedangkan di wilayah dataran rendah, nilai MAE suhu udara maksimum berkisar antara 1.71-1.88 ${ }^{\mathrm{O}} \mathrm{C} /$ hari. Nilai MAE suhu udara minimum terendah merupakan data hasil model MPIESM-MR sebesar $1.71{ }^{\circ} \mathrm{C} /$ hari di wilayah dataran tinggi dan data model MPI-ESM-MR dan MIROC-ESM-CHEM dengan nilai masing-masing sebesar $1.71{ }^{\circ} \mathrm{C} /$ hari dan 1.73 ${ }^{\mathrm{O}} \mathrm{C} /$ hari di wilayah dataran rendah.

Pada Gambar 13a juga dapat dilihat, bahwa dengan melakukan koreksi bias pada data suhu udara minimum pada data hasil model GCMs, menyebabkan nilai MAE suhu udara minimum menjadi lebih kecil. Di wilayah dataran rendah, $\mathrm{BC}$ menyebabkan nilai MAE suhu udara minimum mengalami penurunan sekitar $17 \%$ dibandingan nilai MAE sebelum dilakukan koreksi. Sementara di wilayah dataran rendah, BC dapat menyebabkan penurunan nilai MAE suhu udara minimum $25 \%$ dibandingkan sebelum dilakukan koreksi.

Gambar 13b merupakan gambar grafik perubahan nilai MAE suhu udara minimum sebelum dan setelah dilakukan koreksi yang terjadi di lokasi penelitian, dimana semua model GCMs menunjukan penurunan nilai MAE suhu udara minimum setelah dilakukan koreksi bias dengan rata-rata penurunan sebesar $0.36 \%$, dengan penurunan terbesar terjadi pada model MIROC-ESM dan MRICGCM3 yang mengalami penurunan sebesar $0.40 \%$ setelah dilakukan koreksi bias. Sedangkan pada model lainnya penurunan nilai MAE rata-rata sebesar $0.33 \%$ setelah dilakukan koreksi bias. 


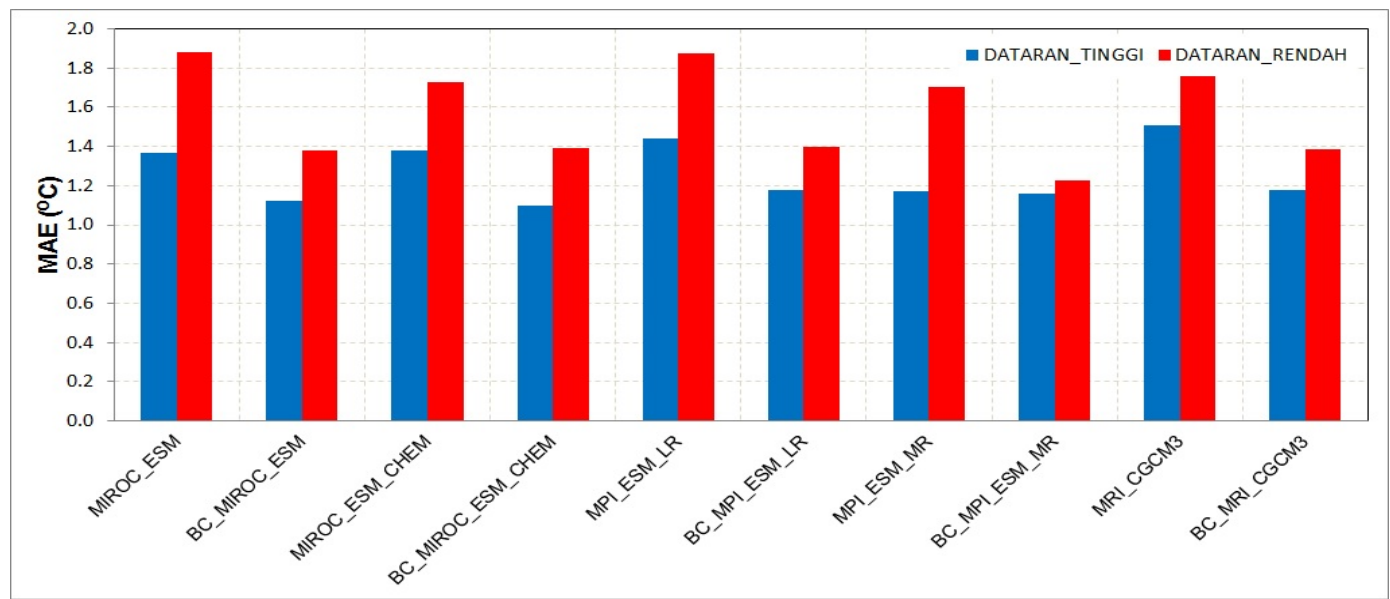

Gambar 13a. Besar nilai MAE suhu udara minimum $\left({ }^{\circ} \mathrm{C}\right)$ data model GCMs dan observasi di wilayah dataran tinggi dan rendah pada lokasi penelitian.

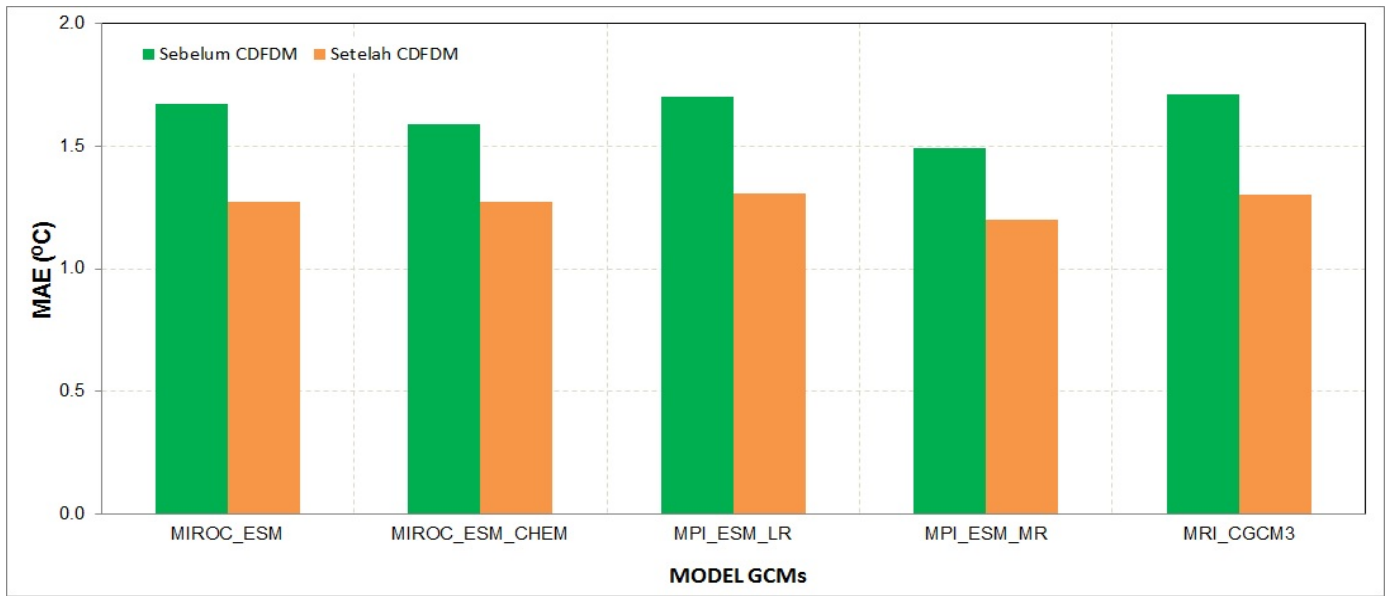

Gambar 13b. Perubahan nilai MAE suhu udara minimum $\left({ }^{\circ} \mathrm{C}\right)$, sebelum dan setelah dilakukan koreksi bias metode CDFDM data model GCMs di lokasi penelitian.

\section{c) RMSE}

Hasil perhitungan nilai RMSE suhu udara minimum data hasil model GCMs dan data observasi di lokasi penelitian, seperti terlihat pada Gambar 14a. Nilai RMSE suhu udara minimum di wilayah dataran rendah lebih besar dibandingkan nilai RMSE suhu udara minimum di wilayah dataran rendah. Nilai RMSE suhu udara minimum di wilayah dataran rendah berkisar antara 2.01-2.24 ${ }^{\circ} \mathrm{C} /$ hari. Sedangkan di wilayah dataran tinggi, nilai MAE suhu udara minimum berkisar antara 1.62-1.84 ${ }^{\circ} \mathrm{C} /$ hari. Nilai RMSE suhu udara minimum terendah merupakan data hasil model MIROC-ESM-CHEM dan MIROC-ESM, dengan nilai masing-masing sebesar 1.62
${ }^{\mathrm{O}} \mathrm{C} /$ hari dan $1.64{ }^{\circ} \mathrm{C} /$ hari di wilayah dataran tinggi. Sedangkan di wilayah dataran rendah, nilai RMSE suhu udara minimum terendah sebesar $2.02{ }^{\circ} \mathrm{C} /$ hari merupakan data hasil model MIROC-ESM dan MIROC-ESMCHEM. Model-model GCMs yang lain mempunyai nilai RMSE suhu udara minimum rata-rata sekitar $2.00^{\circ} \mathrm{C} /$ hari.

Koreksi bias yang dilakukan pada data suhu udara minimum hasil model GCMs mengakibatkan nilai RMSE suhu udara minimum menjadi lebih rendah. Di wilayah dataran rendah, BC menyebabkan nilai RMSE menjadi lebih rendah sebesar $11.41 \%$, seperti yang terlihat pada semua model, kecuali model MIROC-ESM-CHEM. Sedangkan di wilayah 
dataran tinggi, perlakuka $\mathrm{BC}$ pada data suhu udara minimum hasil model GCMs mengakibatkan penurunan nilai RMSE sebesar $18.2 \%$ yang terjadi pada semua model, kecuali model MIROC-ESM-CHEM.

Perubahan nilai RMSE suhu udara minimum sebelum dan setelah dilakukan koreksi yang terjadi di lokasi penelitian, seperti terlihat pada Gambar 14b, dimana nilai RMSE suhu udara minimum pada model semua model mengalami penurunan setelah dilkukan koreksi bias, kecuali pada model MIROC-ESM-CHEM yang terlihat tetap. Penurunan nilai RMSE hasil koreksi sebesar $0.39 \%$. Nilai penurunan terbesar terjadi pada model MPI-ESM-LR dan MRI-CGCM3, yaitu sekitar $0.45 \%$.

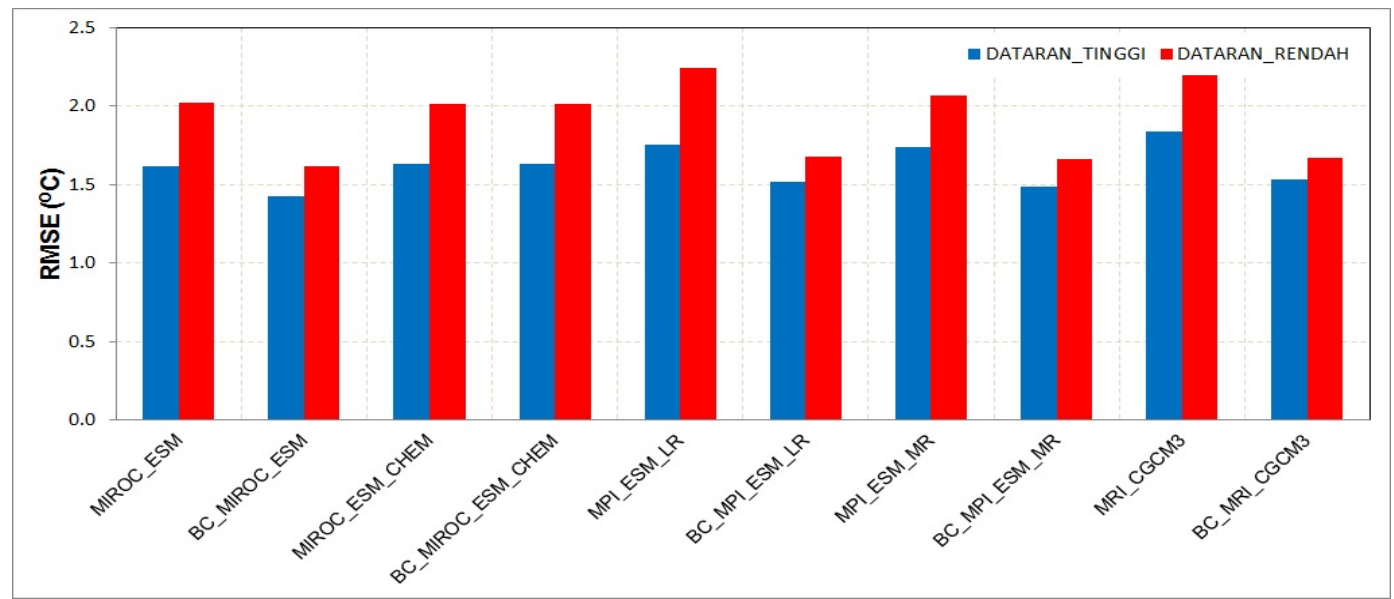

Gambar 14a. Besar nilai RMSE suhu udara minimum $\left({ }^{\circ} \mathrm{C}\right)$ data model GCMs dan observasi di wilayah dataran tinggi dan rendah pada lokasi penelitian.

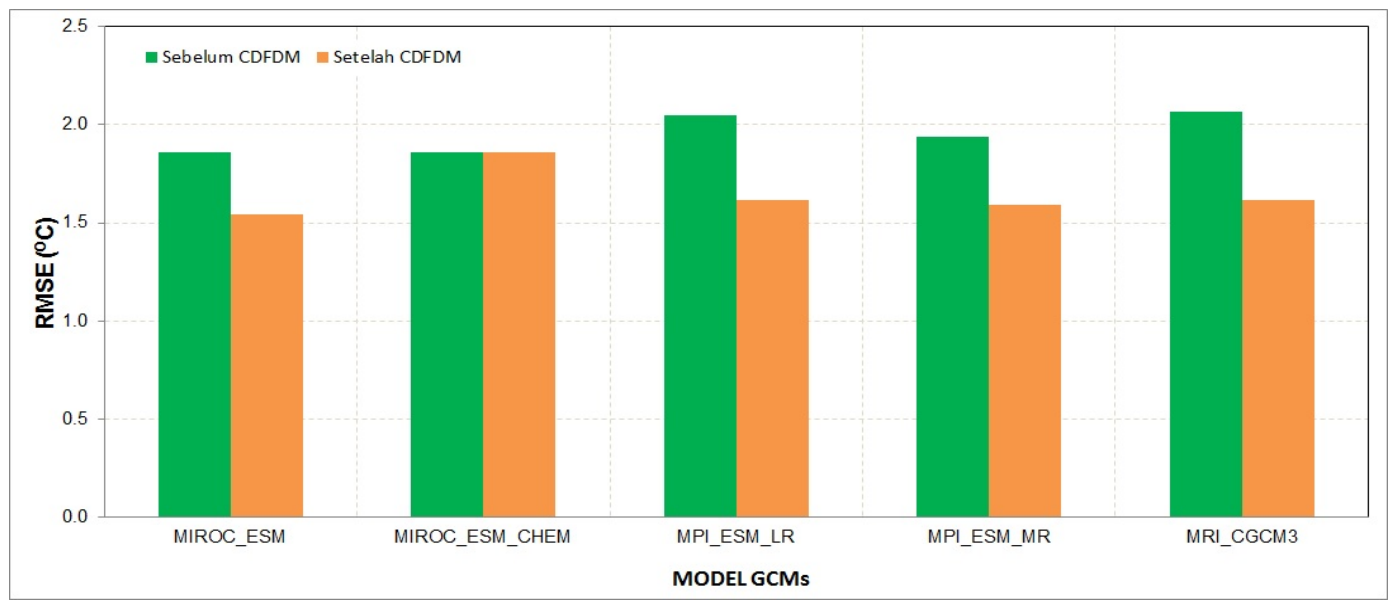

Gambar 14b. Perubahan nilai RMSE suhu udara minimum $\left({ }^{\circ} \mathrm{C}\right)$, sebelum dan setelah dilakukan koreksi bias metode CDFDM data model GCMs di lokasi penelitian.

\section{DISKUSI}

Hasil ekstraksi data GCMs pada NEX-GDDP dataset yang dibandingkan dengan baselinenya menunjukan terjadinya prosentase peningkatan jumlah curah hujan tahunan, suhu udara maksimum dan minimum rata-rata di lokasi penelitian. Hal tersebut berbeda dengan laporan IPCC AR5 yang menyebutkan proyeksi secara global terjadi penurunan jumlah curah hujan dan peningkatan suhu udara (IPCC, 2013). Terjadinya peningkatan jumlah curah hujan juga dilaporkan oleh Malaysian Meteorological Department (2009), dimana pada laporan ilmiahnya tentang 
proyeksi perubahan iklim di Malaysia, menyebutkan adanya peningkatan suhu udara dan kecenderungan terjadi peningkatan curah hujan ekstrim. Proyeksi perubahan iklim yang dilakukan oleh Juneng, dkk., (2012) juga menyimpulkan terjadi peningkatan suhu udara di semenanjung Malaysia akan lebih hangat 3-5 ${ }^{\circ} \mathrm{C}$ hingga tahin 2100 mendatang. Sedangkan untuk curah hujan adanya indikasi peningkatan jumlah curah hujan namun tidak jelas untuk jangka waktu yang panjang. Kesimpulan dari penelitian Boer dan Faqih (2004) dalam laporan konfernsi pers WWF Indonesia tentang Climate Change in Indonesia (Case, dkk., 2007), memproyeksikan perubahan iklim dengan terjadinya peningkatan suhu udara sebesar $0.2-0.3{ }^{\circ} \mathrm{C}$ per dekade dan peningkatan curah hujan tahunan di wilayah Indonesia. Hasil penelitian Daksiya, dkk. (2017) tentang proyeksi frekuensi hujan maksimum harian di sekitar Jakarta dengan menggunkan NEXGDDP dataset menunjukan terjadinya peningkatan curah hujan maksimum di wilayah Jakarta dan sekitarnya yang terjadi pada musim hujan, namum pada musim kering tidak secara jelas kenaikan ataupun penurunannya. Pada sekala lokal Sumatera Barat, juga jelas terlihat perbedaan kenikan curah hujan, suhu maksimum dan minimum untuk di wilayah dataran tinggi dan dataran rendah. Dari kelima model GCMs yang digunakan, hampir semuanya menunjukan kenaikan curah hujan di wilayah dataran rendah lebing tinggi dibandingkan kenaikan curah hujan di wilayah dataran tinggi. Kondisi tersebut berkebalikan dengan suhu udara maksimum dan minimum, dimana persentase kenaikan suhu udara maksimum ataupun minimum lebih besar di wilayah dataran tinggi dibandingkan di wilayah dataran rendah.

Hasil koreksi bias dengan metode CDFDM menunjukan bahwa metode tersebut tidak menujukan performa yang bagus untuk mengoreksi hujan. Hal ini terklihat dari nilai bias, MAE dan RMSE data hujan sebelum dan setelah dilakukan koreksi bias (CDFDM), diaman hasil setelah dilakukan koreksi mempunyai nilai bias, MAE dan RMSE yang lebih besar dibandingkan dengan data sebelum dikoreksi, baik untuk di wilayah dataran tinggi maupun di wilayah dataran rendah. Hasil kajian Iizumi (2011) yang juga menggunakan CDFDM untuk mengoreksi data model dari empat regional climate models (NHRCM, NRAMS, TRAMS, and TWRF) di Jepang menggunakan data curah hujan harian pada periode 1985 - 2004, juga menunjukan metode CDFDM tidak begitu bagus dalam mengoreksi curah hujan ekstrim. Namun Muharsyah (2017), menyimpulkan bahwa koreksi bias dengan metode CDFDM dapat memberikan peningkatan akurasi (jumlah stasiun yang sesuai dengan data observasi) dibandingkan dengan data model sebelum dikoreksi berdasarkan empat indikasi : MEA, INT, FRE dan Q90 terutama pada periode JJA (kering) dengan curah hujan sebesar rata-rata kurang dari $15 \mathrm{~mm} /$ hari. Koreksi bias metode CDFDM menunjukan performa yang lebih bagus dalam koreksi bias suhu udara maksimum dan minimum dibandingkan koreksi bias untuk curah hujan baik itu di wilayah dataran tinggi maupun di dataran rendah terlihat dari nilai bias, MAE dan RMSE yang lebih kecil setelah dikoreksi CDFDM walaupun tidak semua model menunjukan hal tersebut. Perlu ditekankan bahwa CDFDM dapat memperkecil nilai bias untuk data suhu udara maksimum dan minimu tetapi nilai MAE dan RMSE nya tidak emngalami penurunan nilai secara signifikan setelah dilakukan koreksi, bahkan ada beberapa model yang tidak mengalami perubahan nilai. Dilihat dari performa model GCMs yang digunakan terlihat, secara umum bahwa model MPI-ESM-LR dan MPI-ESM-MR mempunyai performa yang bagus untuk data curah hujan dan suhu udara minimum terlihat dari nilai bias model tersebut yang lebih kecil dibandingkan model lainnya. Sedangkan untuk data maksimum, selain kedua model terbaik tersebut, model MIROC-ESMdan MIROCESM-CHEM juga mempunyai tingkat performa yang hampir sama. Ghahreman dkk (2015) dalam penelitiannya untuk investigasi ketidakpastian data hasil proyeksi suhu udara dan curah hujan dengan menggunkan model GCMs luaran IPCC AR5 di wilayah Iran juga menyimpulkan bahwa model MPI-ESM-LR, 
MPI-ESM-MR dan NorEMS1-M, merupakan model-model terbaik dalam proyeksi data iklim.

\section{KESIMPULAN}

Hasil downscaling data GCMs yang dibandingkan dengan baselinenya menunjukan terjadinya persentase peningkatan jumlah curah hujan tahunan, suhu udara maksimum dan minimum rata-rata di lokasi penelitian. Hasil penelitian menunjukkan bahwa CDFDM dapat mengurangi terjadinya bias antara data GCMs dan data Observasi ditunjukan dengan nilai bias yang lebih kecil. Namun besarnya kesalahan (magnitude error) tetap tidak dapat terkoreksi, ditunjukan oleh nilai RMSE dan MAE yang lebih besar setelah dilakukan koreksi. Dari kelima model telihat bahwa model MPI-ESM-LR dan MPI-ESM-MR memiliki performa terbaik dalam memproyeksikan data curah hujan dan suhu udara minimum. Sedangkan untuk suhu udara maksimum, selain kedua model tersebut model MIROC-ESM dan MIROC-ESM-CHEM, juga mempunyai tingkat performa yang hampir sama, baik di wilayah dataran rendah maupun dataran tinggi Sumatera Barat pada periode data tersebut.

\section{DAFTAR PUSTAKA}

Bao, Y and X.Y. Wen (2016). Projection of China's Near-and Long-Term Climate in a New High-Resolution Daily Downscaled Dataset NEX-GDDP. $J$. Meteor. Res., 31(1): 236-249, doi: 10.1007/s13351-07-6106-6.

Cammarano, M., Rivington, K.B. Matthews, D.G. Miller, G. Bellocchi (2016). Implications of climate model biases and downscaling on crop model simulated climate change impacts. Europ $J$. Agronomy.

http://dx.doi.org/10.1016/j.eja.2016.05.0 12

Case M., F Ardiansyah and E Spector (2007). Climate Change in Indonesia: Implication for Human and Nature.
WWF Press Conference, Mahattan Hotel, Jakarta, November 28, 2007.

Daksiya, V., P. Mandapaka, and Edmon Y.M.L. (2017). A Comparative Frequency Analysis of Maximum Daily Rainfall for a SE Asian Region under Current and Future Climate Condition. Advance in Meteorology, Vol. 2017, Article ID 2620798, 16 pages, Hindawi. http://dx.doi.org/10.1155/2017/2620798

Ghahreman, N., M. Tabatabaei and I. Babaeian. (2015). Investigation of Uncertainty in the IPCC AR5 Precipitation and Temperature Projection over Iran under RCP Scenarios. Poster on COP21-CMP11, Paris 2015.

Iizumi T., M. Nishimori, K. Dairaku, S.A. Adachi, M. Yokozawa (2011). Evaluation and intercomparison of downscaled daily precipitation indices over Japan in present-day climate: Strengths and weaknesses of dynamical and bias correction-type statistical downscaling methods. J. Geophys. Res., 116 , D01111, doi:10.1029/2010JD014513.

Malaysian Metorological Department (2009). Climate Change Scenarios fo Malaysia 2001-2099. Scientific Report, Numerical Weather Prediction Development Section Technical Development Division Malaysian Meteorological Department Ministry of Science, Technology and Innovation

Muharsyah, R., (2017). Koreksi Bias Hasil Proyeksi MIROC5 Keluaran WRF dengan Metode CDFDM. Komunikasi pribadi.

Palazzoli, S., Maskey, S., Uhlenbrook, E., Nana dan D. Bocchiola (2015). Impact of prospective climate change on water 
rsources and crop yield in the Indrawati basin, Nepal. Agricultural System 133: 143-157.

http://dx.doi.org/10.1016/j.agsy.2014.10. 016.

Stanski, H, R., L.J. Wilson and W.R Burrows (1989). Survey of Common Verification Methods in Meteorology. Atmospheric Research Report No (MSRB) 89-5, Atmospheric Environment Canada.

Stocker, T.F., D. Qin, G.-K. Plattner, M. Tignor, S.K. Allen, J. Boschung, A. Nauels, Y. Xia, V. Bex and P.M. Midgley (2013). IPCC Summary for Policymakers. In: Climate Change 2013: The Physical Science Basis.
Contribution of Working Group I to the Fifth Assessment Report of the Intergovernmental Panel on Climate Change. Cambridge University Press, Cambridge, United Kingdom and New York, NY, USA.

Tanggang, F. T., I. Juneng, E.Salimum, K. M., Sei L Julle and H. Muhamad (2012). Climate Change and Variability Over Malaysia: Gaps in Science and Research Information. Sains Malaysiana 41(11) : 1355-1366.

Wilby, Robert C.W. Dawson (2007). Statistical Downscaling Model, SDMS Version 4.2 : User Manual. 